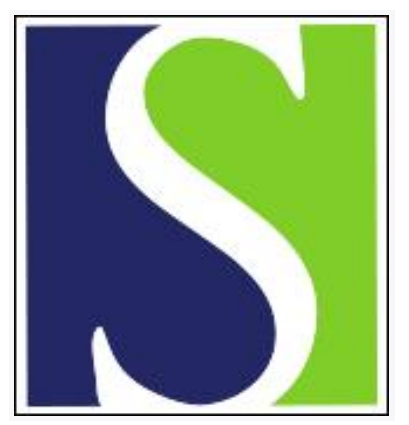

Scand J Work Environ Health 2003;29(6):411-430

https://doi.org/10.5271/sjweh.748

Issue date: Dec 2003

Eye irritation and environmental factors in the office environment-hypotheses, causes and a physiological model by Wolkoff $P$, Skov P, Franck C, Petersen LN

Affiliation: National Institute of Occupational Health, Lersø Parkallé 105, DK-2100 Copenhagen Ø, Denmark. pwo@ami.dk

Refers to the following texts of the Journal: 1999;25(5):442-449

2000;26(6):514-522

The following article refers to this text: 2003;29(6):407-410

Key terms: environmental factor; environmental risk factor; epidemiology; eye irritation; eye symptom; gender difference; indoor air pollution; occupational risk factor; office environment-cause; office environment-hypothesis; physiological model

This article in PubMed: www.ncbi.nlm.nih.gov/pubmed/14712848

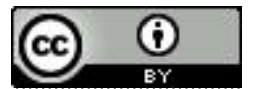




\title{
Eye irritation and environmental factors in the office environment- hypotheses, causes and a physiological model
}

\author{
by Peder Wolkoff, DrMedSc, ${ }^{1}$ Peder Skov, MD, ${ }^{2}$ Carsten Franck, MD, ${ }^{3}$ Lisbeth N Petersen, MD ${ }^{4}$
}

\begin{abstract}
Wolkoff $P$, Skov P, Franck C, Petersen LN. Eye irritation and environmental factors in the office environmenthypotheses, causes and a physiological model. Scand J Work Environ Health 2003;29(6):411-430.

The study reviews eye irritation using a multidisciplinary approach. Potential risk factors and objective gender differences are identified, and possible hypotheses for eye irritation caused by indoor air pollution are discussed. Eye irritation depends somewhat on destabilization of the outer-eye tear film. An integrated physiological risk model with blink frequency, destabilization, and break-up of the eye tear film as inseparable phenomena may explain eye irritation among office workers in terms of occupational, climate, and eye-related physiological risk factors. Certain volatile organic compounds that are both chemically reactive and airway irritants may cause eye irritation. If airborne particles alone should destabilize the tear film and cause eye irritation, their content of surface-active compounds must be high. Personal factors (eg, use of contact lenses, eye make-up, and certain medication) may also affect destabilization of the tear film and possibly result in more eye symptoms.
\end{abstract}

Key terms causes of eye symptoms, gender differences, epidemiology of eye irritation, indoor air pollution, occupational risk factors, environmental risk factors, physiological model for eye irritation.

Eye irritation (eg, dry or strained eyes) is one of the most common symptoms reported in epidemiologic studies on indoor air quality. The symptom "dry eyes" and related ocular-surface effects form the major eye complaint treated by eye physicians $(1,2)$. In recent European and North American studies, the symptom prevalence of eye irritation for men and women (at least once in the past month at work) was reported to be on the order of $25 \%$ to $40 \%$ (3). Several studies have shown that eye and vision problems are frequently reported complaints among persons who work with a visual display unit (VDU). [See, for example, reference 4.] Of the symptoms of the sick-building syndrome, the symptoms "tired and strained eyes" have been reported to be the most common cause of disruption of office work, followed by mental fatigue and headache (5). [For comparison see reference (6).]

The cause(s) of eye irritation in the indoor environment is(are) unknown, although several suspected factors have been studied (7). One hypothesis is that eye and airway irritation is caused by indoor air pollution $(8,9)$. Another, related to VDU work, is that eye and airway irritation is associated with a reduced blink frequency (blinks per minute) and an increase in water evaporation from the precorneal eye tear film, which could result in dehydration of the tear film (10). Destabilization of the tear film by environmental exposure is a third hypothesized cause of eye and airway irritation, in which ruptures increase and the formation of dry spots results in such ocular discomfort as dryness $(2,8,11)$. Symptoms of irritation, including dryness, have also been explained by gland dysfunctions that result in instability of the tear film from deficiencies of one or more of its components $(2,12-15)$ and various kinds of conjunctival inflammation (16).

Many other risk factors, some of which are occupational, are, however, also likely to influence the perception of eye irritation. Some of these are lighting (glare and poor contrast), gaze position, a limited number of breaks, a constant function of accommodation, musculoskeletal burden, and impairment of the visual nervous system. [See, for example, references 17 and 18.] Work stress has also been suggested as an explanation. [See, for example, references 19 and 20.] In addition,

1 Department of Indoor Climate, National Institute of Occupational Health, Copenhagen, Denmark.

2 Roskilde County Hospital, Køge, Department of Occupational Medicine, Roskilde, Denmark.

3 Slagelse County Hospital, Department of Occupational Medicine, Slagelse, Denmark.

4 Glostrup Hospital, Department of Occupational Medicine, Glostrup, Denmark.

Reprint requests to: Dr Peder Wolkoff, National Institute of Occupational Health, Lers $\varnothing$ Parkallé 105, DK-2100 Copenhagen Ø, Denmark. [E-mail: pwo@ami.dk] 
psychological factors (eg, subjectively rated workload, social support by colleagues, individual significance of work, negative trait, job security, and mental fatigue) have been found in multivariate analyses to be associated with an increase in eye irritation among VDU users. [See, for example, references 6 and 21.]

With respect to preventive measures, it is important to understand how physiological effects of indoor pollutants result in an increase in perceived eye irritation in indoor occupational environments. Therefore, our purposes in writing this paper were (i) to review eye irritation reported in the office environment and to identify potential occupational, personal, and other risk factors, especially in relation to indoor air pollution, (ii) to search for objective gender differences, (iii) to propose possible hypotheses for eye irritation caused by indoor air pollution, and (iv) to develop a risk model that integrates known risk factors associated with eye irritation or the exacerbation of eye irritation.

\section{Methods}

The literature was reviewed by a multidisciplinary group with experience in indoor air quality and pollution and occupational medicine, including outer eye examinations in clinical and human exposure studies. The nature of the review was exploratory to stimulate new hypotheses. The literature search strategy included eye symptoms, signs, and symptoms of the sick-building syndrome encountered indoors (eg, discomfort, dryness, excess tearing, foreign body sensation, gravelly sensation, grittiness, itching, inflammation, irritation, lacrimation, ocular fatigue, oppressive eyelids, pain, redness, sandy sensation, scratchiness, smarting, soreness, strain, swollen eyelids, tears in eyes, and tiredness). Various kinds of office equipment (eg, photocopiers) and visual display units (VDU) were also included. Within the physiology of the outer eye, the search strategy included eye tear physiology, blink frequency or rate, breakup time, dehydration or desiccation, dry spots, epithelial damage of the conjunctiva, objective methods, human exposure studies, indoor pollution, indoor air quality, and indoor thermal climate. The search through literature related to indoor air in the field of epidemiology focused specifically on identified associations between eye irritation symptoms, indoor environmental factors, and the use of such office equipment as a VDU, but case reports were generally excluded. In the search for gender differences, only objective measures were identified regarding the outer eye.

The search was carried out in the following databases: Pubmed/Medline, HSline, EMBase, and Scirus. The exclusion criteria were orthoptic, refractive or presbyopic eye and related complaints, work-related musculoskeletal disorders, lighting, organizational and psychological factors, and effects related to inflammatory and allergic diseases and moisturedamaged buildings.

\section{What is eye Irritation?}

Eye irritation has been defined as "the magnitude of any stinging, scratching, burning, or other irritating sensation from the eye [p 188]" (22). Many other vague symptoms and signs of irritation and tiredness have been used in questionnaires. They can be interpreted, however, in different ways that add to the overall confusion, including conceptual and perceptual overlap of reported symptoms $(23,24)$. For example, the symptoms itching, irritation, grating, and sandy sensation have been found to cluster together (25), while the symptoms dryness, smarting, and itching have been found to be related to particular occupations (6). One of the most common symptoms, dryness, has been equated to, and associated with, complaints of irritated eyes, and, in some cases, dryness, itching, and irritation are used in combination. [For comparison see reference 26.]

It has been assumed that the four symptoms itching, smarting, irritation, and dryness are caused by primary sensory reactions ( 5 th cranial nerve, trigeminus) that lead to reported eye irritation (27). It has also been suggested that other eye symptoms are related to different mechanisms. For example, tiredness may be caused by strain of the eye muscles, eye redness due to dilation of the blood vessels may be caused by inflammation or lack of sleep, and cold drafts or emotional stimuli produce lacrimation. Inflammation (eg, posterior blepharitis, conjunctivitis, and other diseases) may further lead to meibomian and lacrimal gland dysfunctions $(2,12,13$, 16, 28).

Eye symptoms are generally considered to be transient and reversible, and they have been reported with intensities from severe (pain, smarting, burning or irritating) to less severe (itchiness, dryness or discomfort) but nevertheless annoying. [For comparison see references 5 and 8.] Questions about eye irritation have so far not included details about the location of the irritation (ie, the inner and exterior eyelids versus the eyeball itself), diurnal variation, onset, duration, and alleviating factors. [For comparison see reference 12.] In addition, the same symptom(s) can arise in association with different diseases. For example, dry eyes and meibomitis both result in sandy-gritty irritation, and the symptoms are insidious at the onset (2). Similarly, it can be difficult to differentiate between dry eyes and allergic conjunctivitis (12). Several diseases and conditions 
can give the same clinical dry-eye picture (16), but with alteration in different layers of the tear film.

The large number of symptoms of eye irritation or their clusters may be related to different perceptions (eg, dry or smarting), which again may reflect different mechanisms that are difficult to differentiate (24). Different disciplines have used different terminology [eg, "eye irritation" is common in occupational hygiene, while physiologists refer to "visual fatigue or strain", and ergopthalmologists look for occupational asthenopia (visual disturbances)]. [For comparison see reference 29.] In addition, differences in the cultural perception of symptoms cannot be excluded. Therefore, different outcomes may have been studied. For example, in one study $21 \%$ of 524 consecutive eye patients reported tired eyes (ocular fatigue) and $15 \%$ were diagnosed as having dry eyes (by objective criteria) (30). Of the patients reporting tired eyes, $71 \%$ were diagnosed as having dry eyes, and, similarly, $51 \%$ of the dry-eye patients reported tired eyes. Since there appears to be many interdependent mechanisms resulting in eye symptoms, an operational unambiguous definition of eye irritation does not seem possible. It is, however, possible that clusters of symptoms could be associated with specific mechanisms. [For comparison see references 6 and 12.]

\section{Physiology of the outer eye}

\section{Tear film components and stability}

The ocular surface, consisting of the cornea, bulbar, tarsal conjunctiva (including glands), and goblet cells, is covered by the tear film $(11,31)$. The cornea is the transparent window covering the front of the eye, while the conjunctiva is the thin transparent tissue that covers the outer surface of the eye from the outer edge of the cornea to the inside of the eyelids. The tear film has many functions (ie, to provide the cornea with a smooth surface with a refraction index greater than air and to maintain integrity by preventing water evaporation from the surface to keep the outer eye moist). The surface tension of the tear film is lower than that of water and thus results in a tighter attachment to the globe by lubrication. Higher surface tension has been measured in persons with dry eyes than in normal persons, a finding compatible with a much lower time for rupture of the tear film among the former (32). In addition, the tear film provides protection against environmental exposure, bacterial colonization, and injury of the ocular surface.

The tear film is continuous over the cornea, but probably more scattered in the conjunctival regions; however, this assumption has not been documented. In a common model, two major layers cover the cornea and conjunctiva. [For comparison see references 11, 13, and 3336 and see figure 1.] An innermost mucus layer covers the epithelium with the adsorbed (mostly) glycoproteins (mucin) secreted from the conjunctival goblet cells between the epithelium cells. Overlying this layer is the intermediate aqueous-mucin layer secreted mainly from the lacrimal glands. Finally, the superficial (precorneal) layer is a thin tear film, lipid (oily) layer secreted from the meibomian glands in the eyelids. The oil is constantly secreted, but it is also aided by the blink action and is almost jetted into the tear film immediately following a blink.

Aqueous tear production varies throughout the day, depending on stimuli through a reflex loop connecting the ocular surface with the lacrimal glands.

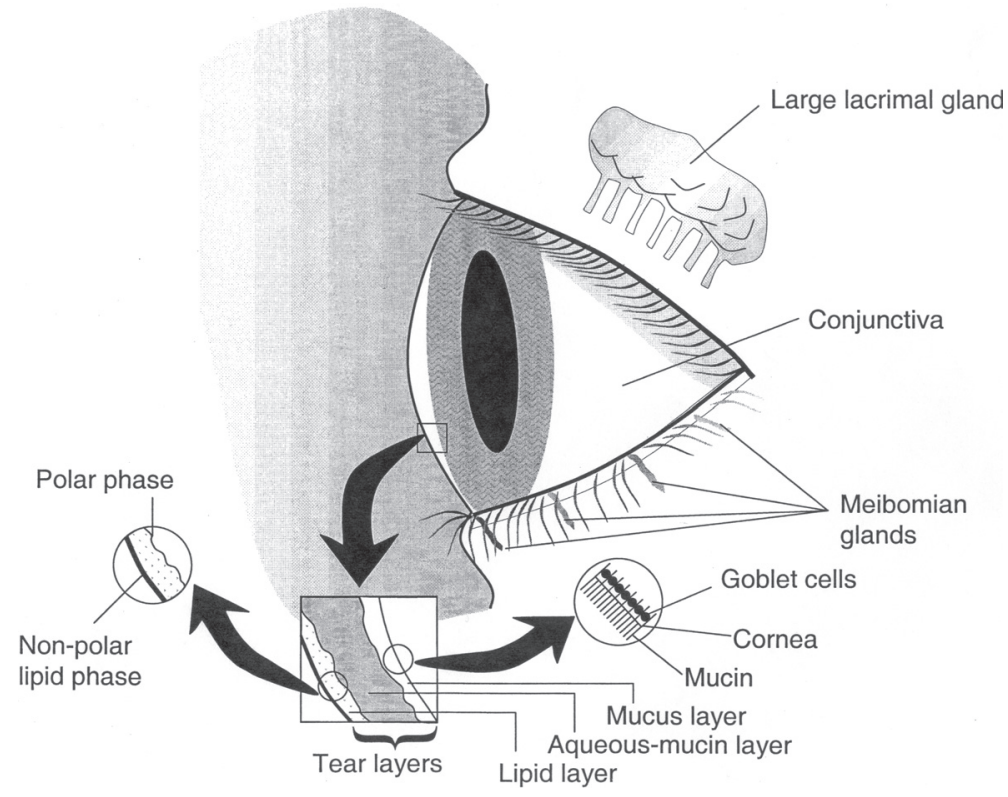

Figure 1. Saggital view of the eye tear film and glands. 
[For comparison see reference 11.] In normal situations, the tear fluid is secreted mainly from the lacrimal and meibomiam glands located in the eyelids, and about $90 \%$ is drained through the lacrimal sac (15). The high abundance of microvilli on the epithelium surface may facilitate the adherence of the mucus layer and subsequently the stability of the tear film.

\section{Factors influencing blinking and the formation of tear film}

The tear film itself is formed by a complex interaction of the blink process, the mucosal surface, the molecules forming it, and the eyelids. It is possible to classify blinking into three categories (37). Voluntary blinking is the result of a conscious decision to close and open the eyelids. Involuntary, spontaneous blinking, however, occurs without any external stimulus and at a fairly constant frequency; this type of blinking probably arises from the activity of a central "blink generator" in the brain, although the neural basis is poorly understood. [For comparison see reference 38.] Reflex blinking is a rapid closure movement of short duration in response to a variety of external stimuli, usually auditory, cognitive, trigeminal, or visual, included as a component of other types of motor behavior.

Table 1. Examples of blink frequency, ocular surface area, and water evaporation as a function of work conditions and climate parameters. (VDU = visual display unit)

\begin{tabular}{|c|c|c|c|c|c|c|}
\hline \multirow[t]{2}{*}{ Condition } & \multicolumn{2}{|c|}{$\begin{array}{c}\text { Blink } \\
\text { frequency/ } \\
\text { min }\end{array}$} & \multicolumn{2}{|c|}{$\begin{array}{c}\text { Ocular } \\
\text { surface } \\
\text { area }\left(\mathrm{cm}^{2}\right)\end{array}$} & \multicolumn{2}{|c|}{$\begin{array}{c}\text { Water } \\
\text { evaporation } \\
(\mu \mathrm{g} / \mathrm{eye})\end{array}$} \\
\hline & Mean & SD & Mean & SD & Mean & SD \\
\hline Relaxed ${ }^{a-c}$ & $13-22$ & 9 a & $2.2^{\mathrm{a}, \mathrm{d}}$ & 0.4 & $0.7^{\mathrm{a}, \mathrm{d}}$ & 0.4 \\
\hline Reading a book at table level ${ }^{\mathrm{a}}$ & 10 & 6 & $1.2^{\mathrm{e}}$ & 0.4 & $1.8^{e}$ & 0.7 \\
\hline VDU work ${ }^{a}$ & 7 & 7 & $2.3^{\dagger}$ & 0.5 & $2.4^{f}$ & 0.6 \\
\hline \multicolumn{7}{|l|}{ VDU work $\mathrm{g}$} \\
\hline Room illumination $120 \mathrm{~cd} / \mathrm{m}^{2}$ & $\eta^{2} 10.1$ & 9 & . & . & . & . \\
\hline Room illumination $30 \mathrm{~cd} / \mathrm{m}^{2}$ & 7.1 & 7 & . & $\cdot$ & . & . \\
\hline \multicolumn{7}{|l|}{ Constant relative humidity $20 \% \mathrm{~h}$} \\
\hline $20^{\circ} \mathrm{C}$ & 17.5 & 8 & . & . & . & . \\
\hline $50^{\circ} \mathrm{C}$ & 6.2 & 3 & . & $\cdot$ & . & . \\
\hline \multicolumn{7}{|l|}{ Constant temperature $20^{\circ} \mathrm{C}$} \\
\hline Relative humidity $80 \%$ & 9.1 & 3 & . & $\cdot$ & . & . \\
\hline \multicolumn{7}{|l|}{ Constant temperature $24^{\circ} \mathrm{C}$} \\
\hline Relative humidity $18 \%$ & 24 & 17 & . & . & . & . \\
\hline Relative humidity $80 \%$ & 17 & 9 & . & . & . & . \\
\hline
\end{tabular}

a Tsubota \& Nakamori (45), $\mathrm{N}=104$.

b Patel et al (50), $\mathrm{N}=16$.

c Carney \& Hill (46), N=20.

d Downward gaze.

e Looking straight ahead.

$\mathrm{f}$ Upward gaze.

9 Tsubota et al (47), $\mathrm{N}=10$.

${ }^{\mathrm{h}}$ Mori et al (55); Tsubota et al (56), $\mathrm{N}=4$.

i Kay et al (48).
The purpose of normal blinking is twofold, to restore the tear film and to defend the eye from environmental exposure (eg, mechanical removal of deposited particles and cellular debris) (15). About $80 \%$ of involuntary blinking is complete, and the descending upper eyelid covers more than two-thirds of the cornea; $18 \%$ is incomplete, and the descending eyelid covers less than two-thirds of the cornea; only $2 \%$ is twitch blinking (flutter); see references in Collins et al (39). Incomplete or no blinking results in the thinning of the lipid layer and a destabilized tear film. For example, a $40 \%$ reduction in the thickness of tear film has been measured 15 seconds after blinking (40). For some eyes, thinning leads to rupture before the next blink, and dry spots are formed that expose the cornea and conjunctiva to pollutants within a limited period of time (34). The time interval (seconds) between blinking and rupture is called the break-up time of the tear film, and this time is considered to reflect the stability of the tear film. In normal persons, the break-up time exceeds the interval between blinks, and, therefore, the tear film is maintained.

Blink frequencies are individual with mean frequencies of $<2-3$ to $20-30$ blinks/minute, and they depend on environmental factors and, possibly, on the use of contact lenses $(15,41)$. Typical blink frequencies at rest range from about 12 to 20 blinks/minute $(15,41)$, lowest at a discrete observation (42). In a study of 150 healthy subjects, the most common order of decreasing blink frequency was found to be conversation > rest > reading (43). Blink frequency during reading also depends on the position of the gaze, being lowest during a low gaze (44). Blinking has been reported to increase due to draft (ie, air velocities higher than $0.5 \mathrm{~m} / \mathrm{s}$ ), but it is suppressed during a visual task (38). Nevertheless, both result in irritation, probably due to a disturbance of the lipid layer, for example, through increased water evaporation that causes a temperature decrease (10).

The major determinants of the blink frequency at rest are extrinsic factors, like dehydration, arising from local tear film conditions around the cornea and conjunctiva and stimulation of their sensory receptors $(10,38)$. Mental activities and work conditions, room temperature, relative humidity, and illumination also influence blink frequency (table 1). Both high temperature and high relative humidity reduce blink frequency. Visual performance demand (ie, work difficulty, complexity, and overload) also results in lower blink frequencies (49). VDU work is an important factor that reduces blink frequency and at the same time enhances the interblink interval significantly (50). For contact lens wearers, the break-up time is lower at low relative humidity (51).

An intact tear film reduces evaporation by $90-95 \%$ (13), but the reduction may increase fourfold if the tear fluid is not confluent or the lipid layer is unstable (52) [eg, because of film thinning $(33,53)$ or mucus 
deficiency caused by a disease (54)]. It has been found that the blink frequency is inversely proportional to the ambient temperature $(55,56)$ [see also Paschides et al (57) and Smedbold et al (58)] with respect to the decrease in break-up time. For normal persons, the threshold for detecting a cooling effect on the cornea is small, about $0.3^{\circ} \mathrm{C}$ over about $0.8 \mathrm{~mm}^{2}$ in less than 1 second of stimulation (59). An increase in relative humidity decreases blink frequency (table 1). However, blink frequency is also influenced by psychological and mental states of mind. For example, mental stress, cognitive awareness and demands, and the tasks performed can play a role $(15,43,44)$. In addition, increased attention generally decreases blink frequency, while anxiety or high arousal increases it (60), in addition to conversation (43). It appears that visual attention reduces blink frequency in proportion to visual demand, while mental problem solving leads to an increase in blink frequency (44) (table 1). Gaze, however, also appears to be an important factor influencing blink frequency, which is highest during direct gaze and lowest during downward gaze (44) (table 1). Blink frequency has also been shown to depend on the frequency of the VDU screen. Blink duration becomes shorter, and the blink interval becomes longer, at low cathode frequencies (61).

An increase in blink frequency may also be stimulated by ocular discomfort, as experienced by dry eye patients and people exposed to tobacco smoke, including side-stream tobacco smoke $(22,62)$. The increase possibly occurs to maximize tear supply and clearance $(15,41)$. Dry eye patients are characterized by a significantly lower maximum blink interval (longest time during which patients comfortably keep their eyes open) than healthy persons (10). One reason for an increase in blink frequency could be more water evaporation from dry eye patients.

\section{Destabilization of tear film}

It is generally assumed that a decrease in secretion from the meibomian and lacrimal glands and the goblet cells leads to destabilized tear film (14). The tear secretion decreases as age increases, mostly among women above 40-60 years of age $(54,63-67)$. This decrease, in part, may contribute to the greater prevalence of eye irritation generally found for women. [See, for example, reference 64.] A thick lipid layer protects against the development of dry eyes; however, some thinning of the lipid layer occurs during a workday in offices $(68,69)$. The break-up time appears also to decrease with increasing age, starting above 40-60 years of age $(35,58,67$, $70,71)$, and is thus consistent with an increase in dry eyes with increasing age (64) and reduced tear secretion among elderly people, particularly among women.
The addition of quartz or benzalkonium chloride to bovine meibomian secretions was found to reduce surface tension significantly (72). [For comparison see reference 73.] Surface tension is probably a predictor of tear film stability; for example, a negative correlation has been found between surface tension and break-up time (noninvasive) (32). A decrease in break-up time (self-reported, measured as time before discomfort or pain is perceived after a blink) has been attributed to emissions of volatile organic compounds (VOC), boiling point about $50-260^{\circ} \mathrm{C}$, from degraded flooring made of polyvinyl chloride (74). In another study, an increase in relative humidity from $35 \%$ to $43 \%$ had no effect on break-up time (self-reported), although the perception that the air was dry was reduced significantly (75). It has been found that break-up time is lower in dry and warm environments than in cold and humid ones (57). Similarly, break-up time was inversely associated with increasing temperature among female nurses, in addition to dust settlement rate (possibly a proxy for airborne particles), and urban vicinity (traffic-related pollution) (58). [For comparison see reference 76.]

\section{Trigeminal stimulation by indoor pollutants}

Blink frequency has been shown to correlate negatively with break-up time; in other words, blink frequency is low in persons with a high break-up time (10, 77-79). This phenomonen indicates that perceived eye irritation (trigeminal stimulation) is associated with an increase in blink frequency since the cornea and conjunctiva both have sensitive nerve endings that belong to the first trigminal branch $(34,37)$. These findings support the hypothesis that changes in tear film prior to its break-up is perceived by the cornea (and possibly conjunctiva) and subsequently triggers a reflex blink (39). Although auditory and visual stimuli cause blinking, trigeminal stimulation dictates most reflex blinking (37). Environmental tobacco smoke at relatively high concentrations is one example of an irritant that can cause a decrease in break-up time (80); such exposure can also result in an increase in blink frequency $(41,80)$. Increases in blink frequency have also been observed in other human exposure studies with different VOC. For example, a butyl acetate concentration of $1400 \mathrm{mg} / \mathrm{m}^{3}$ has resulted in a significant increase, from 9 to 12 blinks/ minute, although the break-up time remained unchanged (81). [For comparison see reference 82.] Exposure to a mixture of VOC $\left(12-24 \mathrm{mg} / \mathrm{m}^{3}\right)$ resulted in a dose or time-dependent increase in blink frequency that was associated with eye irritation (83). However, such dependencies were not found for exposure to ethyl-, methyl tbutyl ether or propylene glycol monoethylether (84-86). Blink frequency has been found to increase from about 21 to 35 blinks/minute after 35 minutes of continuous 
exposure to formaldehyde, from 0.04 to $4 \mathrm{mg} / \mathrm{m}^{3}$ (most clearly at 1.4 to $4 \mathrm{mg} / \mathrm{m}^{3}$ ); in the same interval, eye irritation was reported to increase from 1.3 to just above 2 on a scale from 1 (not at all) to 4 (strong) (62). However, the effects observed at industrial levels cannot be extrapolated to indoor levels. In addition, the measurement of blink frequency differed in the studies and excluded the time necessary for a full cycle of involuntary blinking.

\section{Eye symptoms in the indoor climate}

\section{Eye diseases affecting tear film}

The eye disease "dry eyes" has been classified into "tear-deficient dry eyes" and "evaporative dry eyes" (2). The former is divided into "non-Sjögren dry eyes" and "primary Sjögren's syndrome dry eyes". The cause of the latter is alteration in the aqueous layer $(1,2,87)$. The evaporative type includes several disorders and gland dysfunctions, including also disorders caused by the use of contact lenses $(12,13,36,53,88)$. The prevalence of keratoconjunctivitis sicca has been estimated to be about $4 \%$ in a 30 - to 60 -year-old population when a cutoff value of $5 \mathrm{~mm} / 5$ minutes was used for the Schirmer test, more frequently among elderly people. In the same study, mild primary Sjögren's syndrome was estimated to be on the order of $0.2-0.8 \%$ according to the Copenhagen criteria, and its occurrence was age dependent (87). More than $90 \%$ of patients with primary Sjögren's syndrome in the United States are women (2). These numbers depend on the criteria used for diagnosis. For example, in the diagnosis of dry eyes, the cutoff value for the break-up time is lower than 10 seconds, and for the Shirmer test it is lower than $5 \mathrm{~mm} / 5$ minutes according to a modified scheme (89), whereas, in Japan, the break-up time or the results of the Shirmer test must be lower than 5 seconds or $5 \mathrm{~mm} / 5$ minutes, respectively (30). The prevalence of treated dry eyes was about $0.5 \%$ in a 10 million managed-care population in the United States, and it was highest among women and the elderly (90). In a study of 524 patients, about $6 \%$ had accommodative and refractive abnormalities. [For comparison see reference 91.] In addition, 4\% reported tired eyes associated with eye diseases (30). Moreover, unrecognized optometric defects and eye diseases can contribute to the baseline prevalence of perceived eye complaints in the general population (2). Some of the more important defects are astigmatism, convergence insufficiency, epiphora, myopia, and presbyopia. [For comparison see reference 6.] In addition, there are meibomian gland dysfunctions, avitaminosis, and ocular pemphigoid $(13,92)$. Finally, low-grade infection of the meibomian glands in the eyelids can lead to abnormalities in tear lipid secretion and create a destabilized tear film. However, limited information is available about the specific contribution to eye irritation in the general population. Finally, hormone replacement treatment during menopause may increase the prevalence of dry eyes among women (93). For example, it has been postulated that androgen loss may play a role in glandular dysfunctions and possibly facilitation of an inflammatory environment, which may be reversed by androgen replacement; however, the exact role is unclear. [For comparison see references 2 and 28.] Using the aforementioned studies as a basis, we propose that about $5 \%$ of the general population has eye diseases that may contribute to the baseline prevalence of eye irritation symptoms.

\section{Epidemiology of eye symptoms in office environments}

Knowledge of the prevalence of eye irritation in the general population is important when findings in occupational indoor settings are being evaluated. The prevalence of eye irritation among Danish and Swedish adults has been reported to be about 16-42\% (according to the results of different questionnaires) (27, 87, 94-96). These prevalences are relatively high when compared with the barely $10 \%$ (over the last 4 weeks) found in the working population in a national Danish cohort study (97). Differences in the design of the questionnaires, including symptom type, use of different recall periods, and frequency classes of symptoms, may explain the large differences. For example, in 56 European buildings in 9 countries, the mean prevalence of dry eyes was $39 \%$, expressed as at least once the preceding month. This value dropped to $26 \%$ when people were asked about "experienced at work at this moment" (98). A slightly higher prevalence, but with less difference between retrospective and same day prevalence, was observed in office buildings in the United States (99). Doughty and his colleagues reviewed the literature for eye symptoms and concluded "it was unclear just how often one should expect symptom-free individuals [p 144]" (24).

Possible confounding variables, like the use of contact lenses, medication, and eye cosmetics, have only been addressed in a few studies. [See, for example, references 24, 27, and 91.] For example, 63\% of 292 office employees in an office building complex experienced a mean of 1.8 eye symptoms. However, the identification of contact lens wearers, medication use (in particular for seasonal allergies), including provoking stimuli (eg, traffic) halved the prevalence (the average number of symptoms being 1.5). Of these, only $12 \%$ of the respondents indicated symptoms constantly or often (24). [For comparison see reference 100.] In another study with 2500 participants, the use of contact lenses, a history of allergic conjunctivitis, and VDU work was associated with dry eyes (91). 
Atopy, gender, and psychosocial factors at work are known well as risk factors associated with eye irritation. [For comparison see reference 3.] The odds ratios for eye irritation between women and men are generally between 1.3 and 2.3 in epidemiologic studies. [See, for example, references 3 and 101-104.] For clinical studies the corresponding figure is about $2(9,16)$. It is of note that one recent, although small, study observed an opposite trend (24). It is important that the aforementioned ratios have not been adjusted for confounders, and the findings may as well be ascribed to the type of work women do in organizations rather than to the gender being female.

Use of office equipment, especially work with a VDU, handling photocopy paper, and work near a photocopier are often associated with irritation of the eyes and upper airways $(4,7,105)$. Some studies have indicated that the prevalence of eye irritation is lower in naturally ventilated buildings than in those with mechanical or cooling facilities. [See, for example, references 101,104,106, and 107.]

Different building-related, person-related, and psychological factors are also associated with eye irritation. Some cross-sectional epidemiologic studies have shown an association between VDU work and eye irritation, and, despite major differences in materials and methods, a dose-response effect of VDU workhours appears to be associated with eye irritation $(4,18,108)$. It is of note that redness and watery eyes have not been associated with time spent at work with a VDU (6). The excess prevalence of eye symptoms among VDU users compared with those among nonusers or seldom users varies with odds ratios up to about $2(4,6)$.

A few studies have shown time trends in the development of eye irritation. The mean prevalence for mucus membrane irritation increased slightly from morning to afternoon $(109,110)$. This finding is compatible with the observation that the thickness of the lipid layer decreases during an office workday $(68,69)$. In one study, the prevalence was markedly higher during a period in June than during February (111). This increase, however, may be ascribed to the high temperature or seasonal allergies (112), because allergies may be a major cause of eye symptoms $(24,64,91,113)$ or the use of oral antihistamines. [For comparison see reference 24.] Neither break-up time nor epithelial damage of the conjunctiva appear to exhibit seasonal variation (114).

\section{Reported eye irritation in relation to specific indoor air pollution}

Carpet cleaning has been found to be associated with eye irritation (115-118). The cause is probably excess use or incorrect dilution of the cleaning agent or shampoo remaining in the carpet and dust and subsequently exposure to resuspended particles. In addition, fiber release from ceilings has been associated with eye problems (119). Two cases have been reported about linoleum flooring in schools. Powdering of the floor polish was associated with eye irritation in pupils (120), and, in another case, eye irritation decreased, in particular among pupils, after the replacement of the linoleum flooring with oak parquet flooring (121). The use of indoor paints, particularly for wood surfaces, was associated with eye irritation at the workplace, in particular among women (122). The preceding findings have not been confirmed by follow-ups, and, therefore, a placebo effect cannot be excluded.

Irritants, even stronger than formaldehyde, formed in photochemical reactions in the outdoor air have been associated with eye irritation (123), including formaldehyde and acrolein in tobacco smoke plumes (124).

\section{Studies of eye irritation by objective methods}

\section{Eye irritation in relation to exposure to indoor air pollution}

Studies of objective eye signs of the ocular surface have been carried out in several controlled field studies or in human exposure studies in a climate chamber. Those in which objective eye signs have been documented are summarized in table 2 according to the association between subjective complaints and objective eye signs, the association between office environment exposure and objective eye signs, and the association between controlled exposure to indoor air pollutants and objective eye signs. The objective signs used are common and are used by ophthalmologists to diagnose dry eye conditions or diseases like primary Sjögren's syndrome and keratoconjunctivitis sicca (130). Many of the investigations involved the use of a slit-lamp (bio microscope), with which the ocular surface can be studied before and after vital staining. The effects studied include the affection and stability of the lipid layer and epithelial damage of the conjunctiva. Other methods include examining tear fluid with a phenol red thread or using a microscope to look for different types of cells, including foam formation in the canthus. The examinations reflect different aspects of decreased tear film quality and the consequence thereof (eg, dry spots).

Field studies have found that the prevalence of objective eye signs is often significantly altered among office workers in comparisons with random samples of the general population. [See, for example, references 27,68 , 131, and 132.] This finding appears to be the most pronounced for the buildings with the highest prevalence of irritation symptoms in the eyes, nose and throat. For example, break-up time was significantly lower among 
Table 2. Summary of studies (according to effect studied) in which objective eye signs of the ocular surface have been found to be associated with subjective ocular complaints in office environments or controlled human exposure studies. (VDU = visual display unit)

\begin{tabular}{|c|c|c|c|}
\hline Study by effect studied & Sign & Method & Exposure scenario \\
\hline \multicolumn{4}{|l|}{ Ocular complaints } \\
\hline \multirow[t]{2}{*}{ Franck et al, 1993 (27) } & Lipid layer affection & Slit-lamp examination of foam & Office workers in Copenhagen \\
\hline & Lipid layer stability reduced & Break-up time in slit-lamp & Office workers in Copenhagen \\
\hline Franck, 1986 (132) & Epithelial damage & Slit-lamp examination after vital staining & Office workers in Copenhagen \\
\hline McCarty et al, 1998 (64) & Epithelial damage & Slit-lamp examination after vital staining & General population in Melbourne \\
\hline \multirow[t]{3}{*}{ Brasche et al, 2001 (125) } & Lipid layer affection & Interference pattern, slit-lamp & Office workers across Germany \\
\hline & Lipid layer stability reduced & Break-up time in slit-lamp & Office workers across Germany \\
\hline & Epithelial damage & Slit-lamp examination after vital staining & Office workers across Germany \\
\hline \multicolumn{4}{|l|}{ Office environment exposure } \\
\hline Franck \& Skov, 1989 (131) & Lipid layer affection & Slit-lamp examination of foam & $\begin{array}{l}\text { Office environment compared with } \\
\text { general population }\end{array}$ \\
\hline Franck, 1991 (68) & Lipid layer affection & Interference pattern in slit-lamp & $\begin{array}{l}\text { Office environment compared with } \\
\text { general population }\end{array}$ \\
\hline Franck et al, 1993 (27) & Reduced lipid layer stability & Break-up time in slit-lamp & $\begin{array}{l}\text { Office environment compared with } \\
\text { general population }\end{array}$ \\
\hline Muzi et al, 1998 (134) & Reduced lipid layer stability & Break-up time in slit-lamp & $\begin{array}{l}\text { Air-conditioned buildings compared } \\
\text { with natural ventilation buildings }\end{array}$ \\
\hline \multirow[t]{2}{*}{ Wieslander et al, 1999 (74) } & Self-reported sting & Break-up time & Damp versus specially designed buildings \\
\hline & Self-reported sting & Break-up time & Tobacco smoke in air cabins \\
\hline \multirow[t]{2}{*}{ Fenga et al, 2001 (133) } & Lipid layer stability reduced & Break-up time in slit-lamp & Operating rooms compared with wards \\
\hline & Epithelial damage & Conjunctiva cytology & Operating rooms compared with wards \\
\hline Nakaishi \& Yamada, 1999 (126) & Phenol red thread & Tear secretion & VDU work \\
\hline Kjærgaard \& Brandt, 1993 (76) & Tear fluid & Inflammatory cells & VDU work \\
\hline \multicolumn{4}{|c|}{ Controlled exposure of indoor air pollutants } \\
\hline \multirow[t]{5}{*}{ Johnsen et al, 1991 (127) } & Lipid layer affection & Slit-lamp examination of foam & Rubber floor covering \\
\hline & Lipid layer affection & Slit-lamp examination of foam & Nylon carpet with rubber \\
\hline & Lipid layer affection & Interference pattern in slit-lamp & Rubber floor covering \\
\hline & Lipid layer stability & Break-up time in slit-lamp & Nylon carpet with rubber \\
\hline & Lipid layer stability & Break-up time in slit-lamp & Gypsum board with waterborne paint \\
\hline Kjærgaard et al, 1989 (178) & Lipid layer stability & Break-up time in slit-lamp & n-Decane \\
\hline Wyon \& Wyon, 1987 (128) & Lipid layer stability & Break-up time, slit-lamp & Draft (>1 m/s) \\
\hline Wieslander et al, 2001 (179) & Self-reported sting & Break-up time & Propylene glycol \\
\hline Stokholm et al, 1982 (129) & Epithelial damage & Slit-lamp examination after vital staining & Man-made mineral fibers \\
\hline Wolkoff et al, 1992 (135) & Epithelial damage & Slit-lamp examination after vital staining & Office machines \\
\hline
\end{tabular}

people who worked in operating rooms with air conditioning and reported a significantly higher occurrence of burning, itching, and tearing than those working in wards with natural ventilation (133). In another study, however, it was observed that break-up time was significantly lower among employees in a "sick building" compared with employees in a comparison building with fewer complaints, but no association between break-up time and complaints was found (134). In another study of office workers, there was a significant correlation between use of eye make-up and a thin lipid layer, and the foam formation was significantly reduced in the office population (131). [For comparison see references 13 and 76.]

Objective eye measures have also been used in controlled human exposure studies in climate chambers. For example, exposure to a simulated office environment was found to be associated with epithelial damage of the conjunctiva and reports of eye irritation (135). With a similar approach, but with building materials as sources of VOC, an association was found between reduced tear film quality (pooled break-up time, foam formation, and thickness of lipid layer) and an increase in reported eye irritation (136). In a field study, a weak association was observed between an increase in polymorphonuclear neutrophils in the eye and VDU work (76). Thus office-like environments may promote objective changes in the eyes and be subsequently accompanied by reports of irritation and dryness of the eyes. [See, for example, reference 132.] This, however, is not always the case. [See, for example, references 84, 134 and 137-139.]

\section{Eye irritation in relation to use of contact lenses}

Dry eyes appear to be the most common complaint among contact lens wearers. [See, for example, references 113, 140, and 141.] Although both contact lens wearers and spectacle wearers experience similar eye irritation symptoms, dryness, redness, and grittiness 
have been reported far more frequently among contact lens wearers and with greater severity than among spectacle wearers (141). Several investigations indicate that the use of contact lenses is associated with an increased risk of bacterial adhesion (142), epithelial damage of the conjunctiva (88), inflammation $(143,144)$, reduction of break-up time (145), and, subsequently, dry eyes or eye irritation. The effects appear to be influenced by the lens material and type. [See, for example, references 144 and 146.] Reports of dry eyes among a presbyope population increased from $28 \%$ before contact lenses were acquired to $68 \%$ after 6 months of use, and complaints were the most pronounced among women (145). The use of contact lenses appears to influence dry eye symptoms more than age and gender $(145,146)$. The relatively higher blink frequency among contact lens wearers agrees with complaints often reported about dry eyes or eye irritation $(41,55,88)$, probably because of an increase in the destabilized tear film and water evaporation $(147,148)$.

It has been suggested that maintaining a uniform tear film is hampered by contact lenses and that, during the use of hydrogel lenses, tear film thickness is reduced to about one-third the prewearing phase, and thus can result in the break-up of the tear film and enhanced water evaporation (149). It has also been found that blinking among contact lens wearers is incomplete and can lead to destabilized tear film (35). Contact lens wearers with a low break-up time and lens deposits are more sensitive to low relative humidity (47). Since eye discomfort normally results in the person rubbing his or her eyes, a vicious circle can be instigated among contact lens wearers.

\section{Eye irritation in relation to gender}

The main reason for the higher prevalence of eye irritation often found among women is probably a multicausal phenomenon (150). Indeed, some physiological differences of the outer eye have been found that can at least partially explain the odds ratio between men and women (table 3).

For example, tear film stability (eg, break-up time) is significantly lower among women than among men. In addition, women have a higher blink frequency while reading (43), possibly when oral contraceptives are used (153). This high blink frequency is also compatible with the finding that the mean time of blink suppression is significantly higher for men than for women, while men also appear to be more capable of speeding up their blinking (42). In a recent study of nonallergic Danes, women

Table 3. Observed physiological gender differences of the outer eye. ( $>=$ higher than for men, $<=$ lower than for men)

\begin{tabular}{|c|c|c|c|c|c|}
\hline \multirow[t]{2}{*}{ Study } & \multirow[t]{2}{*}{ Parameter } & \multicolumn{2}{|c|}{ Women } & \multicolumn{2}{|c|}{ Men } \\
\hline & & Mean & SD & Mean & SD \\
\hline Bentivoligio et al, 1997 (43) & Mean blink frequency while reading (blinks/min) & $6.2^{\mathrm{a}}$ & . & 3.0 & . \\
\hline \multirow[t]{2}{*}{ Karson et al, 1981 (42) } & Mean blink suppression (ie, stop blinking as long as possible) (s) & $15^{\mathrm{b}}$ & 15 & 80 & 86 \\
\hline & Blink speed up (blinks/min) & $153^{c}$ & 47 & 220 & 27 \\
\hline Cho \& Yap, 1993 (70) & Mean break-up time (s) (Singapore-Chinese; slit-lamp examination) & $5.6^{d}$ & 3.1 & 8.0 & 4.7 \\
\hline Craig \& Tomlinson, 1998 (154) & Mean break-up time (s) (British; noninvasive method) & $23.8 \mathrm{e}$ & 22.1 & 31.3 & 25.4 \\
\hline \multirow[t]{2}{*}{ Du Toit et al, 2001 (145) } & Mean break-up time (s) (Canadians; slit-lamp examination) & $12.5^{\dagger}$ & . & 17.9 & . \\
\hline & Corneal sensitivity (slit-lamp examination) & $>^{g}$ & . & . & . \\
\hline Cho \& Lam, 1999 (151) & $\begin{array}{l}\text { Corneal thickness decrease with increasing age (slit-lamp } \\
\text { examination) (Hong Kong-Chinese) }\end{array}$ & $>$ & . & . & . \\
\hline Du Toit et al, 2001 (145) & $\begin{array}{l}\text { Damage of conjunctival epithelium after use of contact } \\
\text { lenses (slit-lamp examination) }\end{array}$ & $>$ & . & . & . \\
\hline $\begin{array}{l}\text { Franck, } 1991 \text { (68); Kjærgaard } \\
\text { \& Brandt,1993 (76) }\end{array}$ & Use of eye make-up (slit-lamp examination) & $>$ & . & . & . \\
\hline Lamberts et al, 1979 (65) & Tear secretion (Shirmer's test), after 60 years of age & $<\mathrm{h}$ & . & . & . \\
\hline Tomlinson \& Giesbrecht, 1993 (152) & Water evaporation $\left(\mathrm{g} / \mathrm{m}^{2} \times \mathrm{h}\right)$ & $>$ & . & . & . \\
\hline \multirow[t]{2}{*}{ Craig \& Tomlinson, 1998 (154) } & Osmolality (m0sm/kg) & $<1$ & . & . & . \\
\hline & Linearity with age for women only & $j$ & . & . & . \\
\hline
\end{tabular}

\footnotetext{
a $P=<1 \times 10^{-15}, N=150$.

b $\mathrm{P}=<0.01, \mathrm{~N}=41$.

c $\mathrm{P}=<0.02, \mathrm{~N}=12$.

d $P=0.01, N=76$.

e $P=0.027, N=125$.

if $P=<0.04, N=150$.

g $P=0.01, N=141$.

n $P<0.05$, see also McCarty et al (64) for more information.

i $P=0.012$, age $<41$ years.

j Positive correlation, $\mathrm{P}=0.002, \mathrm{~N}=127$.
} 
who reported eye irritation also had higher levels of epithelial damage of the conjunctiva than men when exposed to carbon dioxide (71). It is of note that women apparently produce less foam in the canthus (76). In a study of presbyopes, women had more epithelial damage of the conjunctiva, more sensitive eyes (ie, lower corneal threshold), and lower break-up time than men after 6 months of wearing contact lenses (145). All in all, women appear to exhibit lower tear film stabilities than men (154). Reports of eye dryness among women are generally twice as high as among men, and women often report being more sensitive (100). For the purpose of comparison, thresholds of nasal irritation due to exposure to carbon dioxide or propanol are lower for women (155), and this phenomenon also accounts for results found in connection with exposure to tobacco smoke (156). It is believed that such differences also occur for eye irritation (through the trigeminal nerve), because anosmic and normosmic persons have comparable sensitivity to nasal and eye irritation (157). The eye irritation threshold of carbon dioxide provocation of the eyes for 2 minutes was about $20 \%$ lower for women than for men, although the result was not statistically significant (158).

Several factors may contribute to gender differences. One is the use of eye make-up, which has been shown to be associated with increased reports of eye irritation among women $(13,68,76,131,159,160)$. Another reason could be that the women in the reported studies have done more VDU work than the men, including lower grade work. A third often-quoted explanation is related to the age-dependent decrease of tear secretion, particularly among women after 40 years of age. [See, for example, references 64, 66, and 161.] Tear secretions are essential substances that help maintain an intact tear film. Androgen and estrogen loss has been postulated to be associated with dysfunctions of the meibomian and lacrimal glands, because their production has been proposed to maintain glandular functions and suppress inflammation. [For comparison see references 2, 11, and 28.]

When the wide differences in experimental conditions and confounders are considered, it can be concluded that there is some evidence for physiological gender differences, and, as also indicated, hormonal factors may result in a higher probability of glandular dysfunctions among women. These findings could in part explain the higher odds ratio of eye symptoms often found for women. In addition, psychosocial factors and personal vulnerability may contribute to the difference. For example, it has been indicated in a human exposure study that occupational stress lowers the threshold for eye irritation (158). It has also been shown that diminished coping (eg, low sense of coherence) with psychosocial challenges merely changes the threshold for expressing symptoms and thereby enhances the reporting, as shown to occur for women (162).

\section{Hypotheses concerning eye irritation due to indoor air pollution}

If eye irritation is caused by indoor pollution, three questions arise. First, which pollutants (gases or particles) cause destabilized tear film and the break-up of tear film, and, second, which pollutants are eye irritants? Since meibomian gland dysfunction and blepharitis with loss of meibomian glands are common causes of evaporative dry eye $(12,13)$, the third question concerns the possibility that indoor pollutants cause gland dysfunctions, in particular in the meibomian glands. It has been suggested that local pathology, dermatological diseases (eg, ocular rosacea), and iatrogenic etiology result in meibomian gland dysfunction (13). One should keep in mind, however, that eye irritation inevitably causes an increase in hand rubbing of the eyes and thus results in an increase of pollutant transport (ie, a vicious cycle). In the following, the first and second questions are discussed in terms of the pollution of particles and gaseous pollutants, respectively, while there is no information available with which to evaluate the third question.

\section{Surface-active compounds and particles}

It has been suggested that eye complaints encountered in the office environment are mild reversible forms of dry eyes of the evaporative type in contrast to the teardeficient dry eyes found in keratoconjunctivitis sicca and primary Sjögren's syndrome (8). It is known that direct instillation of compounds, surfactants [eg, benzalkonium chloride $(73,163)$, paraffin oils, and silicone emulsion (34)] may induce a reduction in surface tension, reduce the lipid layer and break-up time, or enhance epithelial damage of the conjunctiva. However, such outcomes of high local exposure of the eyes are unlikely in the office environment. Instillation of carbon particles (dissolved in perfluorodecalin) into the eye did not result in perceived irritation among 12 volunteers (164). The question is whether indoor particles carry sufficiently high concentrations of surface-active compounds to cause the tear film to break-up or carry eye irritants that result in eye irritation or gland dysfunctions. It has been suggested that fungi and bacteria transferred from a VDU or keyboard to hands that rub eyes could be responsible for conjunctival colonization and result in "tired eyes" (165).

Our present knowledge of surface-active compounds on particles is scarce, except for a few reported cases 
of excess use. Deposition on the forehead, eyes, and skin depends on the electrical charge of the particles and the persons exposed to an electrical field (166). Eye redness and increased subjective complaints have been reported for workers employed in tobacco industries when they were compared with a reference group (167). It was concluded that even small concentrations of tobacco dust could induce acute desquamation of the epithelium layer and increase redness; similarly, tobacco smoke may result in irritation in intercontinental air cabins (168). [For comparison see reference 62.] It is interesting to note a weak association between an increased concentration of polymorphonuclear neutrophils in the eye and VDU work (76), including an association with enhanced epithelial damage of the conjunctiva (135). Traffic pollution, partly reflected as particle settlement on surfaces, has also been associated with eye irritation $(58,76)$. However, it could well be a proxy for other active outdoor, chemically reactive or irritating agent(s). [For comparison see references 169 and 170.]

The results from human exposure studies in climate chambers with exposure to airborne dust from office floors in concentrations of about $400 \mu \mathrm{g} / \mathrm{m}^{3}$ have been inconclusive about eye irritation $(171,172)$. Surfactants in vacuumed office floor dust, like fatty acid salts, and linear alkylbenzene sulfonates used in detergents, have been measured in amounts up to about $0.5 \%$ each (173, 174). They represent, however, only a fraction of the total surface-active agents, which also include proteins (eg, as in human debris). The question is how and how much floor dust can be re-suspended, reach the eye region, and result in irritation. It has been estimated, on the basis of a toxicologic evaluation, that $100 \mu \mathrm{g} / \mathrm{m}^{3}$ of SDS (sodium dodecylbenzene sulfonate) equivalents is the lower limit for airway irritation indoors (175). Therefore, it can be estimated that, to cause airway irritation, airborne particles should contain an unrealistically high percentage of surfactants (in SDS equivalents) at a typical total indoor particle concentration of $50-100 \mu \mathrm{g} / \mathrm{m}^{3}$. (See the preceding comments about the similarity between eye and airway irritation thresholds). In addition, the rate of precipitation of airborne particles reaching the tear film (ie, open unprotected eye) may turn out to be negligible under neutral conditions (no electric fields) and with the person gazing downwards, as in normal office work (176). All in all, if particles at typical indoor concentrations should cause eye irritation, the content of surface-active compounds or eye irritants should be markedly higher than normally encountered.

\section{Gaseous pollutants}

There are indications that certain types of gaseous indoor pollution are associated with objective changes in tear film [eg, in operating rooms compared with wards
(133)]. Outdoor air pollution, in particular reactive compounds like peroxy acetyl nitrates found in smog (123), has also been associated with eye complaints $(170,177)$ or defects of the tear film (58).

Lipophilic and surface-active lipophilic pollutants have been hypothesized to cause thinning of the tear film and destabilized eye tear film and, finally result in reduced break-up time and epithelial damage of the conjunctiva (8). However, both lipophilic and hydrophilic compounds, exemplified by decane and propylene glycol, may result in some reduction of break-up time at industrial concentration levels $(178,179)$; however no reduction has been observed for butyl acetate (81) or propylene glycol monoethyl ether (86). It appears unlikely that such chemically unreactive VOC would result in destabilized tear film at indoor levels. Generally speaking, pollutants other than VOC are present indoors, for example, ozone and nitrogen oxides, including particles on which volatile, semivolatile, and nonvolatile organics, including inorganic substances, are adsorbed. Chemically nonreactive VOC in indoor air are not considered to be a direct cause of eye irritation, because their irritation estimates (for eyes and airways) are orders of magnitude higher than typical indoor concentrations (180). However, reactions between certain unsaturated VOC from pine and citrus oils (eg, used in cleaning agents) and ozone produce airway irritants in mouse bioassays; this phenomenon could possibly explain eye complaints of humans (181). Reactive oxygenated VOC, like formaldehyde and acrolein and other species, are, among other things, formed from these atmospheric reactions, which can occur within the timeframe of low air exchange rates (182). In addition, this hypothesis about reactive species is supported by the fact that ozone-emitting equipment (eg, photocopiers) that can contribute to these reactions locally have been associated with eye and airway irritation (105); it is also supported by the results of a recent eye exposure study of eight men (183).

One hypothesis could be that repetitive exposure to chemically nonreactive VOC increase eye irritation, especially over longer periods. [For comparison see reference 180.] This hypothesis, however, was not supported by the results of a longitudinal study including college students who dissected cadavers in anatomical laboratories. The formaldehyde potency of eye irritation (in addition to nose and throat irritation) diminished during a period of 14 weeks of 2.5 hours of exposure weekly (184). Furthermore, the nasal irritation threshold for nicotine is the same for smokers and nonsmokers, and this similarity indicates that repeated exposure to nicotine does not lower the irritation threshold (185). Repetitive exposures to acetic acid in home environments have been studied for 3 weeks with acetone as a control odorant (186). The response to acetic acid decreased 
during the exposure period, while the response to acetone showed a minor change over the course of the exposure. Since nasal and eye irritation thresholds are comparable (157), it is believed that these observations are also valid for eye irritation. Another hypothesis could be that exposure to a powerful eye and airway irritant increases the effect of a succeeding challenge of chemical nonreactive VOC; however, this assumption was not supported by the results of a mouse bioassay study (187). To conclude, it appears unlikely that chemically nonreactive VOC, even if lipophilic, can result in eye symptoms at indoor concentrations. However, one may speculate that dry spots already formed by destabilized tear film could facilitate VOC at realistic indoor concentrations and stimulate nerve endings in the conjunctival epithelium layer (or eyelids).

Patients with sensory hyperreactivity have been reported to develop eye irritation after exposure of either the airways (eyes covered) or the eyes (airways supplied with fresh air) to perfumes at concentrations significantly greater than in a placebo exposure (188). This finding infers that the olfactory and trigeminal systems do not have completely isolated functions. [For comparison see reference 189.]

\section{Risk model for eye irritation}

Any pathogenetic model for indoor eye irritation must consider the findings from existing studies and previously proposed models $(2,31,35,55,190)$. For example, it is well established that dry eye patients have reduced tear reflex secretion and fewer goblet cells in the conjunctival epithelium. In addition, increased water evaporation thus results in water loss that is sufficient to cause an increase in tear film osmolarity $(1,12,92$, 191). It is also generally believed that destabilized tear film results in enhanced complaints of dry eyes and ultimately in eye irritation (14). [For comparison see reference 179.] Other parameters of interest are the protective mechanisms related to overall tear film quality [ie, conditions that influence blink frequency parameters, lipid layer stability, rate and composition of tear secretions, conjunctival (and corneal) epithelium layer, and the immunologic system]. The symptom of red eyes is generally caused by inflammation (sensory irritation, edema, vessel dilation, white blood cells), exposure to microorganisms, or tissue damage, when the repair mechanisms or the immune system are overwhelmed. Exposure to allergens can also induce inflammation if the person is sensitized.

Our approach has been to formulate a risk model for eye irritation signs and symptoms. It includes their multiple pathogenicities (2), mechanisms $(31,56)$, and the experiences gained from our reviewed studies, as summarized in figure 2. Both experimental and epidemiologic studies on indoor environmental eye irritation indicate different cause-effect relationships. Furthermore, it is difficult to differentiate between the sequence of events, and blink frequency, break-up of the tear film, and destabilized tear film are inseparable phenomena that are influenced by many risk factors. Therefore, we propose a model that integrates most of the risk factors that influence blink frequency, the break-up of the tear film, and destabilized tear film. The mechanism(s) of destabilized tear film and the break-up of the tear film and subsequent dry-spot formation are not well understood. However, water evaporation from the tear film

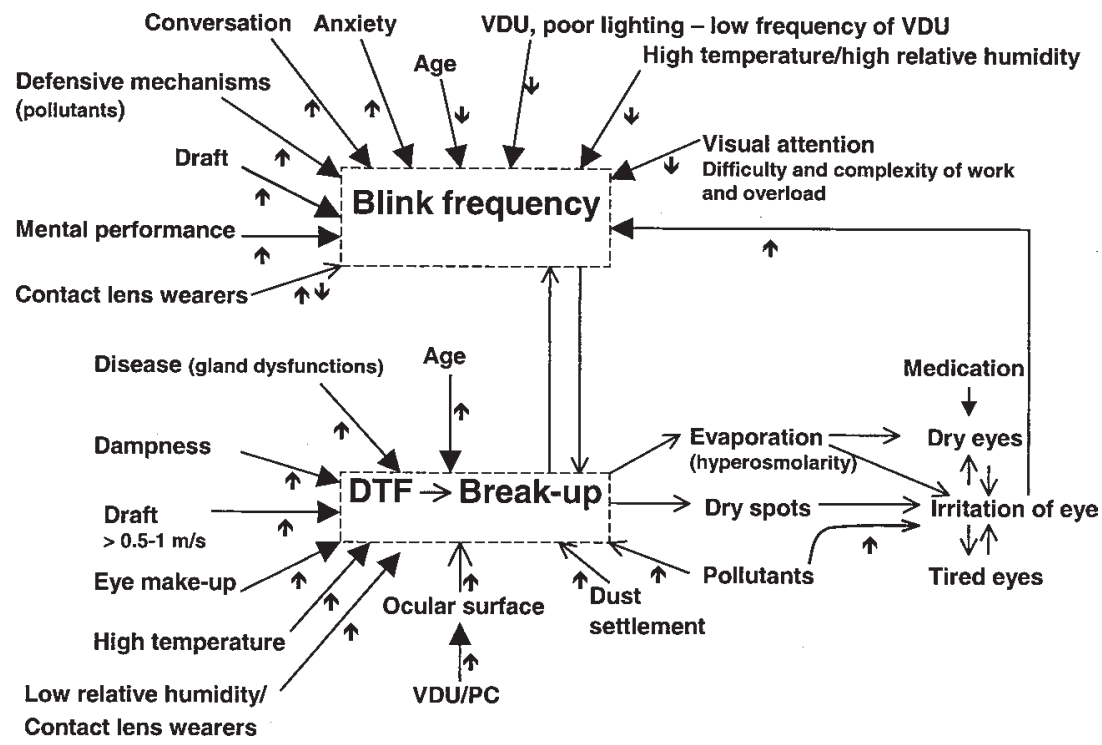

422
Figure 2. Personal and work-related risk factors that influence blink frequency, destabilization of the tear film (DTF), break-up of the tear film with the formation of dry spots, resulting hypothetically in "dry, irritated, and tired eyes". $(\rightarrow=$ more than one paper has demonstrated the impact on either blink frequency or break-up, $\rightarrow=$ only one paper has shown or indicated the impact or the impact is considered hypothetical or both, $\uparrow=$ increase in effect, $\boldsymbol{\downarrow}=$ decrease in effect, $\downarrow \uparrow=$ hypothetical or interactive phenomena, $\mathrm{VDU}=$ visual display unit, $\mathrm{PC}=$ personal computer) 
cannot be the sole mechanism (149), since the break-up time usually lasts less than 1 minute. The most common model assumes uniform evaporation from the tear film to a point that some critical thickness is reached and the lipid molecules in the lipid layer migrate down to the mucus layer, which becomes hydrophobic. Finally, the tear film ruptures and dry spots are formed (35). Spontaneous local thinning of the lipid layer aids the whole process. In the meniscus model, a negative pressure is generated by suction of the curved tear menisci in the lid margins, and this suction induces local thinning of the adjacent tear film $(33,55,192)$. The break-up of the eye tear film in this latter model does not involve the lipid or mucus layers. This assumption is partly supported by the general observation that rupture sites occur more commonly in the parameniscal areas (ie, inferior part) than they do over the central corneal zone. [See, for example, references 146 and 193-195.] The higher proportion of ruptures in the inferior part is compatible with partial or incomplete blinking and thinning of the tear film. [For comparison see references 26, 33, 55, and 196.] It is also compatible with decreases in tear film thickness from the inferior to the superior region of the tear film (149). It is also difficult to separate the cause of dehydration by reduced tear secretion or enhanced water evaporation from the tear film, although water loss by itself appears to cause thinning. [For comparison see reference 190.] Increased osmolarity of the tear film may be one of the sources of epithelial damage of the conjunctiva (1), as a result of water loss that cannot be compensated for by an enhanced rate of tear secretion (eg, among the elderly). This occurrence would result in the perception of dry eyes or eye irritation (11).

The integrated risk model shows that, in addition to the influence of thermal climate, many other factors have a positive or negative influence on both blink frequency and the overall destabilized tear film. The latter leads to thinning and break-up of the tear film or enhanced water evaporation and dehydration of the tear film that results in dry or irritated eyes. The epithelium of the eye is a major protective barrier that regulates transport across the tear film and the inner eye, by making a "tight" sheet with socalled tight junctions. The nerve endings in the eye are just below the surface of the epithelium, which is protected by the mucus layer. Therefore, any rupture of the tear film will facilitate exposure of the nerve endings to pollutants. However, whether dry eyes by themselves also result in reports of eye irritation or tired eyes is unknown. The model only represents some of the many factors that influence the milieu of the outer eye.

One popular explanation for dry eyes is the evaporation of water into the surrounding air as a result of high air velocities near the ocular surface. However, evaporation is insignificant $(<5 \%)$ if the tear film is intact under normal conditions of blink frequency and normal gaze. However, the evaporation increases fourfold in destabilized tear film (54), as well as during VDU work, during which the ocular surface is large and blink frequency is low (table 1). The lipid layer probably acts as a film barrier that retards direct evaporation (ie, external diffusion) because the water loss is dominated by internal diffusion through the lipid layer, rather than by direct evaporation therefrom. [For comparison see reference 149.] The influence of typical indoor air velocities (ie, $<0.15 \mathrm{~m} / \mathrm{s}$ ) on evaporation should be negligible. However, if the lipid layer becomes thinner, water loss may become dominated by direct evaporation. In this case, water evaporation depends on the air velocity and will result in a faster temperature decrease in the cornea. However, high air velocities $(>1 \mathrm{~m} / \mathrm{s})$ have been shown to result in a slight increase in blink frequency during rest, but not during game playing on a VDU (38). In the latter case, VDU work becomes a special case in which performance of a visual task overrides sensory impact from the ocular surface, because the blink frequency falls below that of resting conditions and the exposed ocular surface increases (38). Both reactions result in an increase in water evaporation, possibly as a result of a thinning lipid layer and a subsequent destabilized tear film or vice versa. [For comparison see reference 190.] Suppression of the blink frequency would also cause pollutants to be removed less efficiently. The break-up of the tear film also results in optical aberrations that reduce image quality. This phenomenon may be a direct cause of the blurry vision sometimes reported by complainers of dry eyes (197), perhaps because poor vision would lead to a low blink frequency, because of the increase in visual demand.

The increase in complaints among VDU workers could, among other things, be explained in terms of an increase in osmolarity as a result of dehydration caused by enhanced water evaporation. A higher osmolarity of the tear film results in epithelial damage of the conjunctiva (1), as also observed for women in a simulated office environment study (135).

\section{Practical implications and research needs}

\section{Preventive measures}

Any preventive action should be based on the compiled knowledge available according to table 1 and figure 2 . If work conditions or specific indoor pollutants should destabilize tear film, the result is unlikely to be observed among normal patients in clinics, because the process is reversible and has a relatively short recovery time. The basic problem is how to maintain integrity and wettability of the tear film and to avoid instability (eg, reduction of the blink frequency). In order to minimize 
water loss from the tear film, normal blinking should be maintained in the indoor environment by (i) avoiding room temperatures that are too high, because blink frequency is reduced; (ii) avoiding relative humidities that are too high or too low, because they reduce blink frequency or may increase water evaporation. In order to maintain an intact tear film (i) blinking and short breaks may be beneficial for VDU users (46, 199); (ii) downward gazing is recommended to reduce the ocular surface area and water evaporation (10, 200, 201); (iii) the distance between the VDU and keyboard should be kept as short as possible to minimize evaporation from the ocular surface area by a low direction of the gaze (202); (iv) blink training can be beneficial (203), especially forceful blinking (204). Other preventative measures are (i) proper lid hygiene (13); (ii) avoidance of eye rubbing (165); and (iii) the use of personal products and medication. Eye make-up should be used with care (13). The use of artificial tears may be beneficial in alleviating symptoms, but they should be without preservatives, which destabilize the tear film $(10,163,205)$. The use of oral contraceptives $(93,153)$ and hormonal treatment for postmenopause (161) may increase the risk of dry eyes. Other drugs (eg, antidepressants) may result in hyposecretion or hypersecretion ((31), including medication for hypertension, stomach ailments, and antihistamine $(24,206)$.

\section{Research needs}

The cardinal question about eye irritation in indoor environments is how much is caused by pollutants, how much is disease related, and how much is physiological, psychological, or psychosocial in origin, including musculoskeletal overloading.

Some research needs in relation to indoor air pollution are evident from this review. For example, studies are needed on the interaction (synergism) between common chemically reactive organic compounds and ozone and nitrogen dioxide in concentrations usually found in indoor environments and combined with other loads. Human exposure and effect studies are also needed in which participants are exposed to chemically reactive organic compounds mixed with the aforementioned oxidants under typical work conditions with or without stress or ergonomic load. This work should also include conditions of overloading the accommodation of the eye. In addition, epidemiologic studies of longitudinal design, including intervention, are needed in which groups of office workers with different exposures are followed with measurement of the indoor environment, tear film stability, and symptoms on a personal level. Moreover, clinical longitudinal studies of persons with destabilized tear film should be carried out to determine the natural history of the condition. Finally, the causes of gender differences should be further substantiated and quantified, because of their consistency.

\section{Concluding remarks}

Dry, tired, strained, and irritated eyes are common symptoms in the indoor environment and are often treated by the ophthalmologist. The purpose of this review was to identify risk factors of eye irritation using a multidisciplinary and exploratory approach and to develop a risk model for eye irritation.

Eye irritation symptoms are generally transient in indoor environments. However, occupationally mediated eye irritation, tired (or strained) eyes, and dry eye symptoms are overlapping conditions. It is proposed that about $5 \%$ of the general population has had eye diseases that contribute to the background prevalence.

The pathomechanisms of eye irritation are multiple and complex and depend to some extent on tear film stability. Climatic parameters and occupational risk factors under certain work conditions destabilize the tear film. In an eye physiological risk model, blink frequency, destabilized tear film, and break-up of the tear film are inseparable phenomena that are influenced by a combination of many different risk factors, including personal factors. VDU work, visual attention, and possibly mental problems have an overall destabilization effect on tear film through the process of reducing blink frequency. This reduction may lead to destabilized tear film, and dry spots are formed that may facilitate access of airborne irritants, dehydration, and increased osmolarity, the result thus being dry or irritated eyes. Objective measures of tear film instability in human exposure and field studies have generally been found to be associated with an increase in symptom reporting. Other risk factors are high room temperature or low relative humidity or both. However, a recent review shows that the literature is inconclusive about the influence of low humidity, partly as a result of different study designs. It was concluded, however, that a modest increase in humidity (about $10 \%$ relative humidity) appears to result in some alleviation of symptoms (198).

Destabilization of the tear film may be caused by gland dysfunctions (eg, less tear secretion) provoked by mild inflammation possibly caused by exposure to certain pollutants, in particular among women over 40 to 60 years of age. In addition, the use of contact lenses and eye make-up reduces tear film quality and possibly leads to enhanced water evaporation.

Several well-known risk factors influence the reporting of eye irritation (eg, atopy, gender, and psychosocial factors). Another occupational risk factor is the use of photocopiers. The higher odd ratios often found for eye 
symptoms among women may be explained at least partially by physiological gender differences, possibly hormonal, but more VDU work including lower grade work among women may also contribute to the difference.

Chemically stable VOC and office dust at indoor concentrations are not likely to cause either destabilization or irritation. If the cause(s) of eye irritation should be found among indoor pollutants, those left for speculation are certain chemically reactive VOC known to form airway irritants when mixed with ozone. The tear film may be destabilized if the content of surface-active compounds is high in office floor dust that becomes airborne.

\section{Acknowledgments}

We are indebted to Dr SK Kjærgaard (Aarhus University) and Dr B Piccoli (University of Milan) for their advice and constructive comments. The constructive comments of the anonymous referees are also appreciated.

This work was partly supported by The Danish Working Environment Council and Service Center (2001-25).

\section{References}

1. Bron AJ. Diagnosis of dry eye. Surv Ophthalmol 2001;45:S221-S226.

2. Lemp MA. New strategies in the treatment of dry-eye states. Cornea 1999;18:625-32.

3. Brightman HS, Moss N. Sick building syndrome studies and the compilation of normative and comparative values. In: Spengler JD, Samet, JM, McCarthy JF, editors. Indoor air quality handbook. New York (NY): McGraw-Hill; 2000. p 3.1-3.32.

4. Jaakkola MS, Jaakkola JJK. Office equipment and supplies: a modern occupational health concern. Am J Epidemiol 1999;150:1223-8.

5. Hedge A, Erickson A, Rubin G. Predicting sick building syndrome at the individual and aggregate levels. Environ Int 1996;22:3-19.

6. Aronsson G, Strömberg A. Work content and eye discomfort in VDT work. Int J Occup Saf Ergon 1995;1:1-13.

7. Mendell MJ. Non-specific symptoms in office workers: a review and summary of the epidemiologic literature. Indoor Air 1993;3:227-36.

8. Norn MS. Pollution keratoconjunctivitis. Acta Ophthalmol Scand 1992;70:269-73.

9. Versura P, Profazio V, Cellini M, Torreggiani A, Caramazza R. Eye discomfort and air pollution. Ophthalmologica 1999;213:103-9.

10. Nakamori K, Odawara M, Nakajima K, Mizutani T, Tsubota $\mathrm{K}$. Blinking is controlled primarily by ocular surface conditions. Am Ophthalmol 1997;124:24-30.
11. Rolando M, Zierhut M. The ocular surface and tear film and their dysfunction in dry eye disease. Surv Ophthalmol 2001;45:S203-S210.

12. Gilbard JP. Dry eye, blepharitis and chronic eye irritation: divide and conquer. J Ophthalmic Nurs Technol 1999; 18:109-15.

13. Lozato PA, Pisella PJ, Baudoin C. The lipid layer of the lacrimal tear film: physiology and pathology. J Fr Ophthalmol 2001;24:643-58.

14. Pflugfelder SC, Tseng SCG, Sanabria O, Kell H, Garcia CG, Felix C, et al. Evaluation of subjective assessments and objective diagnostic tests for diagnosing tear-film disorders known to cause ocular irritation. Cornea 1998;17:38-56.

15. Tsubota K. Tear dynamics and dry eye. Prog Retin Eye Res 1998;17:565-96.

16. Versura P, Cellini M, Torreggiani A, Profazio V, Bernabini B, Caramazza R. Dryness symptoms, diagnostic protocol and therapeutic management: a report of 1,200 patients. Opthalmic Res 2001;33:221-7.

17. Murata K, Araki S, Kawakami N, Saito Y, Hino E. Central nervous system effects and visual fatigue in VDT workers. Int Arch Occup Health 1991;63:109-13.

18. Rossignol AM, Morse EP, Summers VM, Pagnotto LD. Video display terminal use and reported health symptoms among Massachusetts clerical workers. J Occup Med 1987;29:1128.

19. Apter A, Bracker A, Hodgson M, Sidman J, Leung W-Y. Epidemiology of the sick building syndrome. J Allergy Clin Immunol 1994;94:277-88.

20. Thomson WD. Eye problems and visual display terminalsthe facts and the fallacies. Opthalmic Physiol Opt 2001;18:111-9.

21. Mocci F, Serra A, Corrias GA. Psychological factors and visual fatigue in working with video display terminals. Occup Environ Med 2001;58:267-71.

22. Walker JC, Nelson PR, Cain WS, Utell MJ, Joyce MB, Morgan WT, et al. Perceptual and psychophysicological responses to non-smokers to a range of environmental tobacco smoke concentrations. Indoor Air 1997;7:173-88.

23. Rolando M, Macri A, Carlandrea T, Calabria G. Use of a questionnaire for the diagnosis of tear film-related ocular surface disease. In: Sullivan AB, editor. Lacrimal gland, tear film, and dry eye syndromes 2. New York (NY): Plenum Press; 1998. p 821-5.

24. Doughty MJ, Blades KA, Ibrahim N. Assessment of the number of eye symptoms and the impact of some confounding variables for office staff in non-air-conditioned buildings. Opthalmic Physiol Opt 2002;22:143-55.

25. Lundin L. On building-related causes of the sick building syndrome [dissertation]. Stockholm: University of Stockholm; 1991. Acta Universitatis Stockholmiensis-Stockholm studies in psychology, vol 7.

26. Guillon J-P. Current clinical techniques to study the tear film and tear secretions. In: Korb RD, Craig J, Doughty M, Guillon J-P, Smith G, Tomlinson A, authors. The tear film. Oxford: Butterworth-Heinemann; 2002. p 51-81.

27. Franck C, Bach E, Skov P. Prevalence of objective eye manifestations in people working in office buildings with different prevalences of the sick building syndrome compared with the general population. Int Arch Occup Health 1993;65:659.

28. Stern ME, Beuerman RW, Fox RI, Gao J, Mircheff AK, Pflugfelder SC. The pathology of dry eye: the interaction between the ocular surface and lacrimal glands. Cornea 
1998;17:584-9.

29. Piccoli B, Pisaniello D, Apostoli P, Halonen L, Mackiw EK. A critical appraisal of current knowledge and future directions of ergophthalmology. Ergonomics 2003;46:384-406.

30. Toda I, Fujishima H, Tsubota, K. Ocular fatigue is the major symptom of dry eye. Acta Ophthalmol Scand 1993;71:34752.

31. Craig JP. Structure and function of the preocular tear film. In: Korb RD, Craig J, Doughty M, Guillon J-P, Smith G, Tomlinson A, authors. The tear film. Oxford: Butterworth-Heinemann; 2002. p 18-50.

32. Tiffany JM, Winter N, Bliss G. Tear film stability and tear surface tension. Curr Eye Res 1989;8:507-15.

33. Wong H, Fatt I, Radke CJ. Deposition and thinning of the human tear film. J Collod Interface Sci 1996;184:44-51.

34. Norn MS. External eye: methods of examination. Copenhagen: Scriptor; 1983.

35. Holly FJ, Lemp MA. Tear physiology and dry eyes. Surv Ophthalmol 1977;22:69-83.

36. Lemp MA. Report of the national eye institute/industry workshop on clinical trials in dry eyes. CLAO J 1995;21:221-32.

37. Sibony PA, Evinger C. Anatomy and physiology of normal and abnormal eyelid position and movement. In: Miller NR, Newman NJ, editors. Walsh \& Hoyt's clinical neuro-ophthalmology. Baltimore (MD): Williams and Wilkins; 1998. p 1509-92.

38. Carmen Acosta M, Gallar J, Belmonte C. The influence of eye solutions on blinking and ocular comfort at rest and during work at video display terminals. Exp Eye Res 1999;68:663-9.

39. Collins M, Seeto R, Campbell L, Ross M. Blinking and corneal sensitivity. Acta Ophthalmol Scand 1989;67:525-31.

40. Ehlers N. The precorneal film. Acta Ophthalmol Scand 1965;Suppl 81:5-136.

41. Monster AW, Chan HC, O'Connor D. Long-term trends in human eye blink rate. Biotelemetry Pat Monit 1978;5:20622.

42. Karson CN, Berman KF, Donnelly EF, Mendelson WB, Kleinman JE, Wyatt RJ. Speaking, thinking, and blinking. Psychiatry Res 1981;5:243-6.

43. Bentivoglio AR, Bressman SB, Cassetta E, Caretta D, Tonali $\mathrm{P}$, Albanese A. Analysis of blink rate patterns in normal subjects. Mov Disord 1997;1028-34.

44. Cho P, Sheng C, Chan C, Lee R, Tam J. Baseline blink rates and the effect of visual task difficulty and position of gaze. Curr Eye Res 2000;20:64-70.

45. Tsubota K, Nakamori K. Dry eyes and video display terminals. N Engl J Med 1993;328:584-4.

46. Carney LG, Hill RM. The nature of normal blinking patterns. Acta Ophthalmol Scand 1982;60:427-33.

47. Tsubota K, Toda I, Nakamori K. Poor illumination, VDTs, and desiccated eyes. Lancet 1996;347:768-9.

48. Kay DLC, Heavner DL, Nelson PR, Jennings RA, Eaker DW, Robinson $\mathrm{JH}$, et al. Effects of relative humidity on nonsmoker response to environmental tobacco smoke. In: Proceeding of the 5th International Conference on Indoor air Quality and Climate; 1990 July 29-3 August; Toronto, Canada; 1990; vol 1. Ottawa: Canada Mortage and Housing Corporation, 1990. p 275-280.

49. Brookings JB, Wilson GF, Swain CR. Psychophysiological responses to changes in workload during simulated air traffic control. Biol Psychol 1996;42:361-77.

50. Patel S, Henderson R, Bradley L, Galloway B, Hunter L. Effect of visual display unit use on blink rate and tear stabili- ty. Optom Vis Sci 1991;68:888-92.

51. Nilsson SEG, Andersson L. Contact lens wear in dry environments. Acta Ophthalmol Scand 1986;64:221-5.

52. Craig JP, Tomlinson A. Importance of the lipid layer in human tear film stability and evaporation. Optom Vis Sci 1997;74:8-13.

53. McDonald JE, Brubaker S. Miniscus-induces thinning of tear films. Am Ophthalmol 1971;72:139-46.

54. Tomlinson A, Craig JP. Time and the tear film. Oxford: Butterworth-Heinemann; 2002. p 83-103.

55. Mori A, Oguchi Y, Okusawa Y, Ono M, Fujishima H, Tsubota K. Use of high-speed, high-resolution thermography to evaluate the tear film layer. Am Ophthalmol 1997;124:72935.

56. Tsubota K, Hata S, Mori A, Nakamori K, Fujishima H. Decreased blinking in dry saunas. Cornea 1997;16:242-4.

57. Paschides CA, Stefaniotou M, Papageorgiou J, Skourtis P, Psilas K. Ocular surface and environmental changes. Acta Ophthalmol Scand 1998;76:74-7.

58. Smedbold HT, Ahlen C, Norbäck D, Hilt B. Sign of eye irritation in female hospital workers and the indoor environment. Indoor Air 2001;11:223-31.

59. Murphy PJ, Patel S, Morgan PB, Marshall J. The minimum stimulus energy required to produce a cooling sensation in the human cornea. Opthalmic Physiol Opt 2001;21:407-10.

60. King DC, Michels KM. Muscular tension and the human blink rate. J Exp Psychol 1957;53:113-6.

61. Jaschinski W, Bonacker M, Alshuth E. Accommodation, convergence, pupil diameter and eye blinks at a CRT display flickering near fusion limit. Ergonomics 1996;39:152-64.

62. Weber-Tschopp A, Fischer T, Grandjean E. Reizwirkungen des formaldehyds (HCHO) auf den menschen [Irritating effects of formaldehyde on men]. Int Arch Occup Health 1977;39:207-18.

63. Cho P, Douthwaite W. The relation between invasive and noninvasive tear break-up time. Optom Vis Sci 1995;72:1722.

64. McCarty CA, Bansal AK, Livingston PM, Stanislavsky YL, Taylor HR. The epidemiology of dry eye in Melbourne, Australia. Ophthalmology 1998;105:1114-9.

65. Lamberts DW, Foster CS, Perry HD. Schirmer test after topical anesthesia and the tear meniscus height in normal eyes. Arch Ophthalmol 1979;97:1082-5.

66. Mathers WD, Lane JA, Zimmerman MB. Tear film changes associated with normal aging. Cornea 1996;15:229-34.

67. Patel S, Farrell JC. Age-related changes in precorneal tear film stability. Optom Vis Sci 989;66:175-8.

68. Franck C. Fatty layer of the precorneal film in the 'office eye syndrome'. Acta Ophthalmol Scand 1991;69:737-43.

69. Norn MS. Desiccation of the pre-corneal film. Acta Ophthalmologica 1969;47:865-80.

70. Cho P, Yap M. Age, gender, and tear break-up time. Optom Vis Sci 1993;70:828-31.

71. Kjærgaard SK, Hempel-Jørgensen A, Mølhave L, Andersson K, Falk J, Juto JE, et al. Eye trigeminal sensitivity, tear film stability, and conjunctival epithelium damage in 1888 nonallergic, non-smoking Danes. Indoor Air. In press.

72. Zhao J, Wollmer P. Air pollutants and tear film stability-a method for experimental evaluation. Clin Physiol 2001;21:282-6.

73. Burstein NL. The effects of topical drugs and preservatives on the tears and corneal epithelium in dry eye. Trans Ophthalmol Soc UK 1985;104:402-9.

74. Wieslander G, Norbäck D, Nordström K, Wålinder R, Venge 
P. Nasal and ocular symptoms, tear film stability and biomarkers in nasal lavage, in relation to building-dampness and building design in hospitals. Int Arch Occup Environ Health 1999;72:451-61.

75. Norbäck D, Wieslander G, Nordström K, Wålinder R, Venge $P$. The effect of air humidification on symptoms and nasal patency, tear film stability, and biomarkers in nasal lavage: A 6 Weeks' longitudinal study. Indoor Built Environ 2000; 9:28-34.

76. Kjærgaard SK, Brandt J. Objective human conjunctival reactions to dust exposure, VDT-work and temperature in sick buildings. In: Jaakkola JJK, Ilmarinen R, Seppänen O, editors. Proceeding of the 6th International Conference on Indoor air Quality and Climate; 1993; July 4-8, Helsinki, Finland; vol 1. Helsinki: Finnish Institute of Occupational Health; 1993. p 41-6.

77. Al-Abdulmunem M. Relation between tear breakup time and spontaneous blink rate. Int Contact Lens Clin 1999;26:11720.

78. Prause JU, Norn MS. Relation between blink frequency and break-up time. Acta Ophthalmol Scand 1987;65:19-22.

79. Yap M. Tear break-up is related to blink frequency. Acta Ophthalmol Scand 1991;69:92-4.

80. Basu PK, Pimm PE, Shephard RJ, Silverman F. The effect of cigarette smoke on the human tear film. Can J Opthalmol 1978;13:22-6.

81. Iregren A, Löf A, Toomingas A, Wang Z. Irritation effects from experimental exposure to $\mathrm{n}$-butyl acetate. Am J Ind Med 1993;24:727-42.

82. Podlekareva D, Pan Z, Kjærgaard S, Mølhave L. Irritation of the human eye mucous membrane caused by airborne pollutants. Int Arch Occup Health 2002;75:359-64.

83. Prah JD, Hazucha M, Horstman D, Garlington R, Case M, Ashley D, et al. Pulmonary, respiratory, and irritant effects of exposure to a mixture of VOCs at three concentrations in young men. In: Jaakkola JJK, Ilmarinen R, Seppänen O, editors. Proceeding of the 6th International Conference on Indoor air Quality and Climate; 1993 July 4-8; Helsinki, Finland; vol 1. Helsinki: Finnish Institute of Occupational Health; 1993. p 607-12.

84. Nihlén A, Löf A, Johanson G. Controlled ethyl tertiary-butyl ether (ETBE) exposure to male volunteers, II: acute effects. Toxicol Sci 1998;46:143-50.

85. Nihlén A, Wålinder R, Löf A, Johanson G. Experimental exposure to methyl tertiary-butyl ether, II: acute effects in humans. Toxicol Appl Pharmacol 1998;148:281-7.

86. Emmen HH, Muijser H, Arts JH, Prinsen MK. Human volunteer study with PGME: eye irritation during vapour exposure. Toxicol Lett 2003;140-141:249-59.

87. Bjerrum KB. Keratoconjunctivitis sicca and primary Sjögren's syndrome in a Danish population aged 30-60 years. Acta Ophthalmol Scand 1997;75:281-6.

88. Itoh R, Yokoi N, Kinoshita S. Tear film instability induced by rigid contact lenses. Cornea 1999;18:440-3.

89. Bjerrum KB. Tear fluid analysis in patients with primary Sjögren's syndrome using lectin probes. Acta Ophthalmol Scand 1999;77:1-8.

90. Yazdani C, McLaughlin, T, Smeeding JE, Walt J. Prevalence of treated dry eye disease in a managed care population. Clin Ther 2001;23:1672-82.

91. Shimmura S, Shimazaki J, Tsubota K. Results of a population-based questionnaire on the symptoms and lifestyles associated with dry eye. Cornea 1999;18:408-11.

92. Dohlman CH, Lemp MA, English FP. Dry eye syndrome. Int
Ophthalmol Clin 1971;10:215-51.

93. Schaumberg DA, Buring JE, Sullivan DA, Dana MR. Hormone replacement therapy and dry eye syndrome. JAMA 2001;286:2114-9.

94. Norbäck D, Edling C. Environmental, occupational and personal factors related to prevalence of Sick Building Syndrome in the general population. Br J Ind Med 1991;48:45161.

95. Hay EM, Thomas E, Pal B, Hajeer A, Chambers H, Silman AJ. Wear association between subjective symptoms or and objective testing of dry eyes and dry mouth. Ann Rheum Dis 1998;57:20-4.

96. Jacobsson LTH, Axel TE, Hansen BU, Henricsson VJ, Larsson A, Lieberkind K, et al. Dry eyes or dry mouth: an epidemiological study in Swedish adults with special reference to primary Sjögren's syndrome. J Autoimmunol 1989;2:521-7.

97. Burr HK, Bach E, Borg V, Villadsen E. Arbejdsmiljø i Danmark 2000: en kortlægning af lønmodtageres og selvstændiges arbejdsmiljø og helbred [Occupational environment in Denmark 2000]. Copenhagen: National Institute of Occupational Health; 2000.

98. Bluyssen PM, De Olivera Fernandes E, Groes L, Clausen G, Fanger PO, Valbjørn O, et al. European indoor air quality audit project in 56 office buildings. Indoor Air 1996;6:22138.

99. Maikin R, Wilcox T, Sieber WK. The national institute for occupational safety and health indoor environmental evaluation experience, part two: symptom prevalence. Appl Occup Environ Hyg 1996;11:540-5.

100. McMonnies CW, Ho A. Responses to a dry eye questionnaire from a normal population. J Am Optom Assoc 1987;58:58891.

101. Hedge A, Burge PS, Robertson AS, Wilson S, Harris-Bass J. Work-related illness in offices: a proposed model of the "Sick Building Syndrome". Environ Int 1989;15:143-58.

102. Bourbeau J, Brisson C, Allaire S. Prevalence of the sick building syndrome symptoms in office workers before and six months and after being exposed to a building with an improved ventilation system. Occup Environ Med 1996; 53:204-10.

103. Chandrakumar M, Evans J, Arulanantham P. An investigation into sick building syndrome among local authority employees. Ann Occup Hyg 1994;38:789-800.

104. Muzi G, Abbritti G, Accattoli MP, Dell’Omo M. Prevalence of irritative symptoms in a nonproblem air-conditioned office building. Int Arch Occup Health 1998;71:372-8.

105. Fisk WJ, Mendell MJ, Daisey JM, Faulkner D, Hodgson AT, Nematollahi M, et al. The California healthy building study, phase I: a summary. Indoor Air 1993;3:246-54.

106. Zweers T, Preller B, Brunekreef B, Boleij JSM. Health and indoor climate complaints of 7043 workers in 61 buildings in the Netherlands. Indoor Air 1992;2:127-36.

107. Mendell MJ, Fisk WJ, Deddens JA, Seavey WG, Smith AH, Smith DF, et al. Elevated symptom prevalence associated with ventilation type in office buildings. Epidemiology 1996;7:583-9.

108. Knave BG, Wibom RI, Voss M, Hedström LD, Bergqvist UOV. Work with video display terminals among office employees, I: subjective symptoms and discomfort. Scand J Work Environ Health 1985;11:457-66.

109. Baird JC, Berglund, B, Esfandabad HS. Longitudinal assessment of sensory reactions in eyes and upper airways of staff in a sick building. Environ Int 1994;20:141-60.

110. Skov P, Valbjørn O, Gyntelberg F, The Danish Indoor Study 
Group. Rådhusundersøgelsen-indeklima i kontorer [The Danish Town Hall Study - the indoor climate in offices]. Copenhagen: Arbejdsmiljøfondet, 1989.

111. Wiesmüller GA., Steup A, Ranft U. Inner room-questionnaire for the German-speaking area. Zentralblatt Hyg Umweltmedizin 1998;202:435-70.

112. Durham S. ABC of allergies. BMJ 1998;316:843-5.

113. Doughty MJ, Fonn D, Richter D, Simpson T, Caffery B, Gordon K. A patient questionnaire approach to estimating the prevalence of dry eye symptoms in patients presenting to optometric practices across Canada. Optom Vis Sci 1997; 74:424-31.

114. Franck C, Boge I. Break-up time and lissamine green ED in 'office eye syndrome'. Acta Ophthalmol Scand 1993;71:624.

115. Berlin K, Johanson G, Lindberg M. Hypersensitivity to 2-(2butoxyethoxy)ethanol. Contact Dermatitis 1995;32:54.

116. Kreiss K, Gonzalez MG, Conright KL, Scheere AR. Respiratory irritation due to carpet shampoo; two outbreaks. Environ Int 1982;8:337-42.

117. Robinson PA, Tauxe RV, Winkler WG, Levy ME. Respiratory illness in conference participants following the use of a carpet shampoo. Infection Control 1983;4:158-60.

118. Schmitt H-J. Reizungen der Atemwege nach Anwendung von Teppichshampoo [Airway irritation by carpet shampoo]. Öff Gesundheitswes 1985;47:458.

119. Thriene B, Sobottka A, Willer H, Weidhase J. Man-made mineral fibre boards in buildings - health risks caused by quality deficiencies. Toxicol Lett 1996;88:299-303.

120. Malmberg B, Leanderson P, Nilsson A, Flodin U. Powdering floor polish and mucous membrane irritation in secondary school pupils. Int Arch Occup Health 2000;73:498-502.

121. Åhman M, Lundin A, Musabašić V, Söderman, E. Improved health after intervention in a school with moisture problems. Indoor Air 2002;10:57-62.

122. Norbäck D, Wieslander, G, Björnsson E, Janson C, Boman G. Eye irritation, nasal congestion, and facial skin itching in relation to emissions from newly painted indoor surfaces. Indoor Built Environ 1996;5:270-9.

123. Altshuller AP. Assessment of the contribution of chemical species to the eye irritation potential of photochemical smog. J Air Pollut Contr Assoc 1978;28:594-8.

124. Ayer HE, Yeager DW. Irritants in cigarette smoke plumes. Am J Public Health 1982;72:1283-5.

125. Brasche S, Bullinger M, Bronish M, Bischof W. Eye- and skin symptoms in German office workers-subjective perception vs. objective medical screening. Int J Hyg Environ Health 2001;203:311-6.

126. Nakaishi H, Yamada Y. Abnormal tear dynamics and symptoms of eyestrain in operators of visual display terminals. Occup Environ Med 1999;56:6-9.

127. Johnsen CR, Heinig JH, Schmidt K, Albrechtsen O, Nielsen PA, Wolkoff P, et al. A study of human reactions to building materials in climatic chambers, part I: performance and comfort. Indoor Air 1991;1:377-88.

128. Wyon NM, Wyon DP. Measurement of acute response to draught in the eye. Acta Ophthalmol Scand 1987;65:385-92.

129. Stokholm J, Norn M, Schneider T. Ophthamological effects of man-made mineral fibers. Scand J Work Environ Health 1982;8:185-90

130. Kjærgaard SK, Hodgson M. The assessment of irritation using clinical methods and questionnaires. AIHAJ 2001;62:711-6.

131. Franck C, Skov P. Foam at inner eye canthus in office work- ers, compared with an average Danish population as control group. Acta Ophthalmol Scand 1989;67:61-8.

132. Franck C. Eye symptoms and signs in buildings with indoor climate problems ('Office Eye Syndrome'). Acta Ophthalmol Scand 1986;64:306-11.

133. Fenga C, Aragona P, Cacciola A, Ferreri F, Spatari G, Stilo $\mathrm{A}$, et al. Ocular discomfort and conjunctival alterations in operating room workers: a single-institution pilot study. Int Arch Occup Health 2001;74:123-8.

134. Muzi G, Dell'Omo M, Abbritti G, Accattoli MP, Fiore MC, Gabrielli AR. Objective assessment of ocular and respiratory alterations in employees in a sick building. Am J Ind Med 1998;34:79-88.

135. Wolkoff P, Johnsen C, Franck C, Wilhardt P, Albrechtsen O. A study of human reactions to office machines in a climatic chamber. J Exp Anal Epidemiol 1992;Suppl 1:71-96.

136. Wolkoff P, Nielsen GD, Hansen LF, Albrechtsen O, Johnsen CR, Heinig JH, et al. A study of human reactions to building materials in climatic chambers. part II: VOC measurements, mouse bioassay, and decipol evaluation in the $1-2 \mathrm{mg} / \mathrm{m}^{3}$ TVOC range. Indoor Air 1991;1:389-403.

137. Schein OD, Tielsch JM, Munõz B, Bandeen-Roche K. Relation between signs and symptoms of dry eye in the elderly. Ophthalmology 1997;104:1395-401.

138. Brown SI. Dry spots and corneal erosions. Int Ophthalmol Clin 1973;13:149-56.

139. Smeets MAM, Mauté C, Dalton P. Acute sensory irritation from exposure to isopropanol (2-propanol) at TLV in workers and controls: objective versus subjective effects. Ann Occup Hyg 2002;46:359-73.

140. Fonn D, Situ P, Simpsom T. Hydrogel lens dehydration and subjective comfort and dryness Ratings in symptomatic and asymptomatic contact lens wearers. Optom Vis Sci 1999;76:700-4.

141. Vajdic C, Holden BA, Sweeney DF, Cornish RM. The frequency of ocular symptoms during spectacle and daily soft and rigid contact lens wear. Optom Vis Sci 1999;76:705-11.

142. Bruinsma GM, van der Mei HC, Busscher HJ. Bacterial adhesion to surface hydrophilic and hydrophobic contact lenses. Biomaterials 2001;22:3217-24.

143. Thakur A, Willcox MDP. Contact lens wear alters the production of certain inflammatory mediators in tears. Exp Eye Res 2000;70:255-9.

144. Versura P, Bernabini B, Torreggiani A, Cellini M, Caramazza R. Frequent replacement and conventional daily wear soft contact lens symptomatic patients: tear film and ocular surface changes. Int J Artif Organs 2000;23:629-36.

145. Du Toit R, Situ P, Simpsom T, Fonn D. The effects of six months of contact lens wear on the tear film, ocular surfaces, and symptoms of presbyopes. Optom Vis Sci 2001;78:45562.

146. Bruce AS, Mainstone JC, Golding TR. Analysis of tear film breakup on Etafilcon A hydrogel lenses. Biomaterials 2001;22:3249-56.

147. Tomlinson A, Cederstaff TH. Water evaporation from the human eye: the effects of contact wear. J Br Contact Lens Assoc 1983;5:141-50.

148. Doughty MJ. Rewetting, comfort, lubricant and moisturising solutions for the contact lens wearers. Contact Lens Anterior Eye 1999;22:116-26.

149. Creech JL, Do LT, Fatt I, Radke CJ. In vivo tear-film thickness determination and implications for tear-film stability. Curr Eye Res 1998;17:1058-66.

150. Gijsbers van Wijk CMT, Kolk AM. Sex differences in physi- 
cal symptoms: the contribution of symptom perception theory. Soc Sci Med 2001;45:231-46.

151. Cho P, Lam C. Factors affecting the central corneal thickness of Hong Kong-Chinese. Curr Eye Res 1999;18:368-74.

152. Tomlinson A, Giesbrecht C. The ageing tear film. J Br Contact Lens Assoc 1993;16:67-9.

153. Yolton DP, Yolton RL, López R, Bogner B, Stevens R, Rao D. The effects of gender and birth control pill use on spontaneous blink rates. J Am Optom Assoc 1994;65:763-70.

154. Craig JP, Tomlinson A. Age and gender effects on the normal tear film. Adv Exp Med Biol 1998;438:411-5.

155. Shusterman D, Murphy MA, Balmes J. The influence of sex, allergic rhinitis, and test system on nasal sensitivity to airborne irritants: a pilot study. Environ Health Perspect 2001;109:15-9.

156. Cometto-Muñiz JE, Cain WS. Sensory irritation-relation to indoor air pollution. Ann N Y Acad Sci 1992;641:137-51.

157. Cometto-Muñiz JE, Cain WS. Trigeminal and olfactory sensitivity: comparison of modalities and methods of measurement. Int Arch Occup Health 1998;71:105-10.

158. Kjærgaard SK, Pedersen OF, Mølhave L. Sensitivity of the eyes to airborne irritant stimuli: Influence of individual characteristics. Arch Environ Health 1992;47:45-50.

159. Kjærgaard SK, Berglund B, Lundin L. Objective eye effects and their relation to sensory irritation in a "sick building". In: Jaakkola JJK, Ilmarinen R, Seppänen O, editors. Proceeding of the 6th International Conference on Indoor Air Quality and Climate, 1993; July 4-8, Helsinki; vol 1. Helsinki: Finnish Institute of Occupational Health; 1993. p 17-122.

160. Yamaguchi T. Conjunctival foreign body from a cosmetic facial scrub. Am Ophthalmol 1995;119:237-9.

161. Mathers WD, Stovall D, Lane JA, Zimmerman MB, Johnson $S$. Menopause and tear function: the influence of prolactin and sex hormones on human tear production. Cornea 1998;17:353-8.

162. Runeson R, Norbäck D, Stattin H. Symptoms and sense of coherence-a follow-up study of personnel from workplace buildings with indoor air problems. Int Arch Occup Health 2003;76:29-38.

163. Wilson WS. Duncan AJ, Jay JL. Effect of benzalkonium chloride on the stability of the precorneal tear film in rabbit and man. Br J Ophthalmol 1975;59:667-9.

164. Zhu Y, Wilson CG, Meadows D, Olejnik O, Frier M, Washington N, et al. Dry powder dosing in liquid vehicles: ocular tolerance and scintigraphic evaluation of a perfluorocarbon suspension. Int J Pharmacol 1999;191:79-85.

165. Piccoli B, Assini R, Gambaro S, Pastoni F, D’Orso M, Franceshini S, et al. Microbiological pollution and ocular infection in CAD operators: an on-site investigation. Ergonomics 2001;44:658-67.

166. Schneider T, Bohgard M, Gudmundsson A. A semiempirical model for particle deposition onto facial skin and eyes: role of air currents and electric fields. J Aerosol Sci 1994;25:58393.

167. Kjærgaard SK, Pedersen OF. Dust exposure, eye redness, eye cytology and mucous membrane irritation in a tobacco industry. Int Arch Occup Health 1989;61:519-25.

168. Wieslander G, Lindgren T, Norbäck D, Venge P. Changes in the ocular and nasal signs and symptoms of aircrews in relation to the ban on smoking on intercontinental flights. Scand J Work Environ Health 2000;26(6):514-22.

169. Schmut O, Gruber E, el-Shabrawi Y, Faulborn J. Destruction of human tear proteins by ozone. Free Radic Biol Med 1994;17:165-9.
170. Stephens ER, Darley EF, Taylor OC, Scott WE. Photochemical reaction products in air pollution. Int $\mathrm{J}$ Air Water Pollut 1961:4:79-100.

171. Hauschildt P, Mølhave L, Kjærgaard SK. Reactions of healthy persons and persons suffering from allergic rhinitis when exposed to office dust. Scand J Work Environ Health 1999;25(5):442-9.

172. Pan Z, Mølhave L, Kjærgaard SK. Effects on eyes and nose in humans after experimental exposure to airborne office dust. Indoor Air 2000;10:237-45.

173. Clausen PA, Wilkins CK, Wolkoff P. Gas chromatographic analysis of free fatty acids and fatty acid salts extracted with neutral and acidfied dichloromethane from office floor dust. J Chromatogr A 1998;814:161-70.

174. Vejrup KV, Wolkoff P. Linear alkylbenzene sulphonates in indoor floor dust. Sci Total Environ 2002;300:51-8.

175. Nielsen GD, Clausen SK, Berqvist M, Sobani S, Hammer M, Hansen LA, et al. Rengøringsmidlers rolle ved udvikling af arbejdsbetingede luftvejslidelser [The role of cleaning agents in the development of occupationally related airway illnesses]. Valby (Denmark): Arbejdsmiljørådets Service Center; 2000. p 1-40.

176. Schneider T, Gudmundsson A, Bohgard M, Nielsen, NF, Hauschildt P, Bengtsson-Stigmar E. Airborne particle deposition on the ocular surface: role of thermophoresis and settling. In: Chalmers University of Technology, editor. Annual Nordic Aerosol Symposium 1997. Gothenburg (Sweden): Chalmers University of Technology; 1997. p 1-31.

177. Heuss JM, Glasson WA. Hydrocarbon reactivity and eye irritation. Environ Sci Technol 1968;2:1109-16.

178. Kjærgaard SK, Mølhave L, Pedersen OF. Human reactions to indoor air pollutants: n-decane. Environ Int 1989;15:473-82.

179. Wieslander G, Norbäck D, Lindgren T. Experimental exposure to propylene glycol mist in aviation emergency training: acute ocular and respiratory effects. Occup Environ Med 2001;58:649-55.

180. Wolkoff P, Nielsen GD. Organic compounds in indoor airtheir relevance for perceived indoor air quality. Atmos Env 2001;35:4407-17.

181. Wolkoff P, Clausen PA, Wilkins CK, Nielsen GD. Formation of strong airway irritants in terpene/ozone mixtures. Indoor Air 2000;10:82-91.

182. Weschler CJ, Shields HC. The Influence of ventilation on reactions among indoor pollutants: modeling and experimental observations. Indoor Air 2000;10:92-100.

183. Klen $\varnothing$ JG, Wolkoff P. Changes in eye blink frequency as a measure of trigeminal stimulation by exposure to limonene oxidation products, isoprene oxidation products and nitrate radicals. Int Arch Occup Environ Health. In press.

184. Kriebel D, Myers D, Cheng M, Woskie S, Cocanour B. Short-term effects of formaldehyde on peak expiratory flow and irritant symptoms. Arch Environ Health 2001;56:11-8.

185. Thuerauf N, Kaegler M, Renner B, Barocka A, Kobal G. Specific sensory detection, discrimination, and hedonic estimation of nicotine enantiomers in smokers and nonsmokers: are there limitations in replacing the sensory components of nicotine. J Clin Psychopharmacol 2000;20:472-8.

186. Hummel T, Dalton P, Dilks DD. Effects of exposure to irritants. Chem Senses 2000;25:788.

187. Rohr A, Wilkins CK, Clausen PA, Hammer M, Nielsen GD, Wolkoff P, et al. Upper airway and pulmonary effects of oxidation products of $(+)$ - $\alpha$-pinene, $d$-limonene, and isoprene in BALB/c mice. Inhal Toxicol 2002;14:663-84.

188. Millqvist E, Bengtsson U, Löwhagen O. Provocations with 
perfume in the eyes induce airway symptoms in patients with sensory hyperreactivity. Allergy 1998;54:495-9.

189. Kendall-Reed M. Approaches to understanding chemosensory responses: new directions and new caveats. AIHAJ 2001;62:717-22.

190. Miller KL, Polse KA, Radke CJ. Black-line formation and the "perched" human tear film. Curr Eye Res 2002;25:15562.

191. Mathers WD, Daley TE. Tear flow and evaporation in patients with and without dry eye. Ophthalmology 1996;103:664-9.

192. Sharma A, Tiwari S, Khanna R, Tiffany JM. Hydrodynamics of meniscus-induced thinning of the tear film. Adv Exp Med Biol 1998;438:425-31.

193. Cho P, Brown B, Chan I, Conway R, Yap M. Reliability of the tear break-up time technique of assessing tear stability and the locations of the tear break-up in Hong Kong Chinese. Optom Vis Sci 1992;69:879-85.

194. Bitton E, Lovasik JV. Longitudinal analysis of precorneal tear film rupture patterns. Adv Exp Med Biol 1998;438:3819.

195. Rengstorff RH. The precorneal tear film: Breakup time and location in normal subjects. Am J Optometry Physiolog Opt 1974;51:765-9.

196. Collins MJ. Stahmer D, Pearson G. Clinical findings associated with incomplete blinking in soft lens wearers. Clin Exp Optom 1989;72:55-60.

197. Tutt R, Bradley A, Begley C, Thibos LN. Optical and visual impact of tear break-up in human eyes. Invest Ophthalmol Vis Sci 2000;41:4117-23.

198. Nagda NL, Hodgson M. Low relative humidity and air cabin air quality. Indoor Air 2001;11:200-14.

199. Henning RA, Jacques P, Kissel GV, Sullivan AB, AlterasWebb SM. Frequent short rest breaks from computer work: effects on productivity and well-being at two field sites. Ergonomics 1997;40:78-91.

200. Barbato G, Ficca G, Muscettola G, Fichele M, Beatrice M, Rinaldi F. Diurnal variation in spontaneous eye-blink rate. Psychiatry Res 2000;93:145-51.

201. Sotoyama M, Villanuveva MBG, Jonai H, Saito S. Ocular surface area as an informative index of visual ergonomics. Ind Health 1995;33:43-56.

202. Sotoyama M, Jonai H, Saito S, Villanuveva MBG. Analysis of ocular surface area for comfortable VDT workstation layout. Ergonomics 1996;39:877-84.

203. Collins M, Heron H, Larsen R, Lindner R. Blinking patterns in soft contact lens wearers can be altered with training. Am J Optometry Physiolog Opt 1987;64:100-3.

204. Levrat F, Pisella PJ, Baudoin C. Clinical tolerance of anticlaucoma eyedrops with and without a preservative: results of an unpublished survey in Europe. J Fr Ophthalmol 1999;22:186-91.

205. Korb DR. The tear film-its role today and the future. In: Korb RD, Craig J, Doughty M, Guillon J-P, Smith G, Tomlinson A, authors. The tear film. Oxford: Butterworth-Heinemann; 2002. p 126-92.

206. Doughty MJ, Fonn D, Caffery B. The Canadian dry eye epidemiology study (CANDEES), a first report. Optom Vis Sci 1995:154-170.

Received for publication: 19 August 2002 